NBER WORKING PAPER SERIES

\title{
DO DISASTER EXPERIENCE AND KNOWLEDGE AFFECT INSURANCE TAKE-UP DECISIONS?
}

\author{
Jing Cai \\ Changcheng Song \\ Working Paper 22403 \\ http://www.nber.org/papers/w22403 \\ NATIONAL BUREAU OF ECONOMIC RESEARCH \\ 1050 Massachusetts Avenue \\ Cambridge, MA 02138 \\ July 2016
}

We are grateful to Liang Bai, Michael Carter, Stefano DellaVigna, Frederico Finan, Benjamin Handel, Jonas Hjort, Shachar Kariv, Botond Koszegi, David Levine, Ulrike Malmendier, Edward Miguel, Stefan Nagel, Matthew Rabin, Gautam Rao, Emmanuel Saez, and Dean Yang for helpful comments and suggestions. We thank the People's Insurance Company of China for their close collaboration at all stages of the project. The study was funded by Xlab at UC Berkeley and the 3ie. All errors are our own. The views expressed herein are those of the authors and do not necessarily reflect the views of the National Bureau of Economic Research.

NBER working papers are circulated for discussion and comment purposes. They have not been peer-reviewed or been subject to the review by the NBER Board of Directors that accompanies official NBER publications.

(C) 2016 by Jing Cai and Changcheng Song. All rights reserved. Short sections of text, not to exceed two paragraphs, may be quoted without explicit permission provided that full credit, including $(\odot$ notice, is given to the source. 
Do Disaster Experience and Knowledge Affect Insurance Take-up Decisions?

Jing Cai and Changcheng Song

NBER Working Paper No. 22403

July 2016

JEL No. D03,D14,G22,M31,O16,O33,Q12

\begin{abstract}
$\underline{\text { ABSTRACT }}$
This study examines the effect of experience and knowledge on weather insurance adoption. First, we conduct insurance games with farmers, and find that the treatment improves real insurance take-up by $46 \%$. The effect is not driven by changes in risk attitudes and perceived probability of disasters, or by learning of insurance benefits, but is driven by the experience acquired in the game. Second, we find that providing information about the payout probability has a strong positive effect on insurance take-up. Finally, when subjects receive both treatments, the probability information has a greater impact on take-up than does the disaster experience.
\end{abstract}

\author{
Jing Cai \\ Department of Economics \\ University of Michigan \\ 611 Tappan Street \\ Ann Arbor, MI 48109 \\ and NBER \\ caijing@umich.edu \\ Changcheng Song \\ National University of Singapore \\ Department of Economics \\ Singapore 119077 \\ ecsscc@nus.edu.sg
}




\section{Introduction}

Financial development plays an important role in economic growth. However, the diffusion of new financial services is usually slow ${ }^{1}$. One example of a new financial product with a particularly low spontaneous take-up rate is weather insurance. Despite its importance in shielding farmers from weather-related risks and in influencing their production investment (Cole et al. (2013b), Karlan et al. (2014a), Cai (2015)), the take-up rate of weather insurance products is extremely low even with heavy government subsidies. Existing research has explored a number of possible explanations for this low take-up rate, including a lack of trust, a lack of financial literacy, or credit constraints (Giné et al. (2008); Gaurav et al. (2011); Cole et al. (2013a); Cai et al. (2015)). However, insurance demand remains low even after some of these barriers are removed in an experimental setting. In this paper, we use a novel randomized experimental design to study two less well-explored factors that may impact insurance adoption: one is personal experience with disaster, and the other is knowledge of the payout probability.

First, experience with natural disasters may influence individual insurance purchase decisions. However, the relative infrequency of large natural disasters means that individuals do not experience the benefits of insurance until a disaster happens. Moreover, people who have different disaster experiences may also be different in other aspects, such as education, life expectancy, etc. To address these challenges in investigating the role of experience on insurance adoption decisions, we use insurance games to simulate hypothetical experience with disasters. Using this approach, we are able to exploit the exogenous individual-level

\footnotetext{
${ }^{1}$ For example, Cole et al. (2013a) finds only a 5-10\% take-up rate for a new rainfall insurance policy in rural India. Hong et al. (2004) shows that the stock market participation rate is only about $48 \%$ in the United States, and Karlan et al. (2014b) documents that only $22 \%$ of adults worldwide report having a formal savings account. However, there are also some examples of rapid diffusion, such as the use of M-Pesa in Kenya (Aker and Mbiti (2010), Jack and Suri (2014)).
} 
variation in hypothetical experience to disentangle the effects of hypothetical experience from other potentially confounding effects, including changes in people's risk attitudes, perceived probability of future disasters, and perception of insurance benefits.

Second, many financial products have low take-up because people are uncertain about the expected returns, as typically only ex-post outcomes are observed. In this paper, taking advantage of a key feature of weather insurance products - payouts are determined by exogenous weather shocks, we provide the first study to show how offering information regarding the true expected returns of a financial product affects adoption decisions.

To study the role of disaster experience and knowledge on individual insurance take-up decisions, we designed a randomized experiment based on the introduction of a new weather insurance policy for rice farmers offered by the People's Insurance Company of China (PICC), China's largest insurance provider. The experiment includes two interventions. In the first intervention, we test how hypothetical experience affects insurance demand. Specifically, we provide participants with hypothetical experience regarding weather shocks and insurance benefits by playing an insurance game. During the game, we first ask a household head whether he/she would like to buy rice insurance in a hypothetical future year. We then play a lottery to determine if the participant experiences a weather-related disaster in that year. After the lottery, we help participants calculate their hypothetical income for the year based on their insurance decision. We play the game with each participant for 10 rounds to establish a base of hypothetical experience of weather shocks and insurance.

Next, one or three days after the game intervention, we visit each participant and ask whether he/she would like to purchase weather insurance. The results show that participating in the game increases the actual insurance take-up by 9.1 percentage points, a $46 \%$ increase relative to the baseline take-up rate of 20 percentage points. This effect is roughly 
equivalent to experiencing a $45 \%$ greater loss in yield in the past year, or a $45 \%$ increase in the perceived probability of future disasters.

Examining the mechanisms that drive this increase in insurance adoption, we find that the main mechanism is the hypothetical experience itself. We arrive at this conclusion by first examining subjects' post-game risk attitudes and perceptions of disaster probability. The results indicate that neither attitude nor perception changes by an amount which could generate the observed 9.1 percentage point increase in insurance take-up after the game.

We next examine whether learning about insurance benefits is responsible for the observed effect. To test this mechanism, we estimate the impact of a pure insurance education treatment on take-up, and we find no significant effect. Moreover, we show that the game treatment does not affect households' insurance knowledge significantly.

Lastly, we test whether the game effect is driven by the hypothetical experience with disasters. To do so, we explore the exogenous variation in the number of hypothetical disasters experienced during the game. The results show that the total number of disasters significantly increases the take-up rate, with the number of disasters in last few rounds exhibiting the strongest effect. Specifically, experiencing one additional hypothetical disaster in the last five rounds increases insurance take-up by 7 percentage points. This suggests that hypothetical experience with disasters might be the main mechanism driving the game effect.

We further explore why experiences in the latter part of the game have a larger impact on real insurance take-up. There are three likely explanations. First, participant memory may decrease over time, leading them to be more likely to remember more recent experiences. Second, recent hypothetical experience makes disasters more salient to farmers. Third, subjects may fail to iterate and believe that only the last rounds of game caused the overall game outcomes. We rule out the decline in memory as the reason because of the short time 
frame of the experiment. Moreover, we show that a greater number of hypothetical disasters in latter rounds of the game also increases the perceived probability of disasters. We thus conclude that the recency effect is more likely due to a salience effect or failure of iteration rather than decreasing memory over time.

In the second main intervention of the experiment, we test whether improving knowledge about the product value affects insurance demand by revealing the real probability of disaster to a randomly-selected set of farmers in our experiment. Doing so, we find a large positive effect of the probability treatment on insurance adoption: farmers who are informed about the real disaster probability are almost 30 percentage points more likely to buy the insurance.

Interestingly, for the set of farmers who receive both knowledge and experience, we find that knowledge of disaster probability has a greater impact on insurance adoption, especially when the disaster probability indicated by the game is higher than the true probability. This finding also provides insight into how financial education can be better designed to increase product adoption ${ }^{2}$. Specifically, our study shows that information on the true expected values of financial assets could be important in improving the effectiveness of financial education.

Finally, we examine the impact of our intervention on household welfare. To explore this question, we calibrate insurance take-up using a benchmark model and the parameters elicited from our surveys (See Appendix B for details). Our results show that the calibrated insurance take-up rate is $58.6 \%$ at the post-subsidy price (3.6 RMB) and $47.3 \%$ at the full price (12 RMB). Specifically, the game treatment increases the take-up rate from about 20 to $30 \%$. Thus, we conclude that our interventions are likely to help individuals make better decisions, although the take-up rate obtained after our intervention is still far from the

\footnotetext{
${ }^{2}$ The literature suggests mixed results on the effectiveness of financial education in increasing product adoption (Duflo and Saez (2003); Bayer et al. (2008); Carlin and Robinson (2012); Gaurav et al. (2011); Cole et al. (2013); Drexler et al. (2014); Cai et al. (2015)).
} 
benchmark level. However, we should note that our intervention increases insurance take-up regardless of the quality or price of the insurance product; thus, whether our intervention is welfare-improving depends on the context.

This paper relates to the existing literature in several ways. First, this paper sheds light on the slow diffusion of new technologies and financial products in emerging markets. We show that playing insurance games with farmers simulates hypothetical experience of disasters and increases the real insurance take-up. The large impact of the game treatment and the insignificant effect of the calculation treatment suggest that, giving households a rule of thumb to follow through simulated experiences could be more effective in improving their decision-making compared with offering theoretical training ${ }^{3}$. This insight can be used on a broader level to influence the adoption of other products and activities that (1) involve uncertainty and (2) require some time to experience the gain or loss. Moreover, the observed large effect of revealing the true probability of disasters on insurance adoption shows that helping people understand the true expected value of the insurance product has an impact on their subsequent choices. Many other financial decisions also involve complexities that individuals have difficulty understanding based on their own information. Our findings suggest that providing information on the true expected values of financial assets in financial education programs could be important in improving individual decision-making.

Second, our results also relates to the literature on the effect of personal experience on individual decision-making. Although existing studies have shown the effect of experience on consumption and financial decisions (Gallagher (2014); Haselhuhn et al. (2009); Malmendier and Nagel (2011); Kaustia and Knüpfer (2008)), the impact of simulated experience on household behavior has been largely unexplored with one notable exception: Gaurav et

\footnotetext{
${ }^{3}$ This result is consistent with Drexler et al. (2014), which shows that rule-of-thumb training is more effective than standard accounting training in improving micro-entrepreneurs' financial decision making.
} 
al. (2011) study the impact of financial education obtained via an insurance game on real insurance take-up in India. The key difference between our study and Gaurav et al. (2011) is that we exploit the exogenous individual-level variation in hypothetical experience to disentangle the effects of hypothetical experience from other potentially confounding effects.

Third, this paper contributes to the literature on recency effects by exploring the mechanism behind such effects. Within this body of literature, several lab and field experiments (Fredrickson and Kahneman (1993); Schreiber and Kahneman (2000); Haisley and Loewenstein (2011); Erev and Haruvy (2013); Healy and Lenz (2014); Karlan et al. (2014a)) show that recent experiences play a stronger role in influencing subsequent behaviors. Our study contributes to this research by showing that the number of disasters in last few rounds of the game has a stronger effect on both insurance take-up and the perceived probability of disasters than the number in earlier rounds. We conclude from this finding, as well as the brief nature of our game, that the recency effect is due to a salience effect or failure of iteration rather than reductions in participant memory.

Lastly, from the perspective of methodology, we demonstrate that laboratory experiments can serve as interventional mechanisms in obtaining field results. We do so by testing the causal effect of the laboratory experiment itself on actual behavior in the field. This design differs from the more commonly used design of having all subjects participate in both a laboratory experiment and a field intervention, and correlating behaviors across the two (Ashraf et al. (2006); Gazzale et al. (2011); Fehr and Goette (2007); Benz and Meier (2008)).

The rest of the paper is organized as follows. In Section 2, we provide background information on rice insurance in China. In Section 3, we describe the experimental design. In Section 4, we explain the main empirical results. Section 5 concludes. 


\section{Background}

Nearly $50 \%$ of farmers in China produce rice, which represents the staple crop for more than $60 \%$ of the Chinese population. In 2009, The People's Insurance Company of China designed the first rice insurance program in China and offered it to rural households in 31 pilot counties.

We conduct the experiment in 16 natural villages within two of the rice production counties included in the government's first round pilot of the insurance program. Our sample counties are located in Jiangxi province, which is one of China's major rice bowls. All households in these villages were offered with the formal rice insurance product.

The insurance contract is as follows. The full insurance premium is $12 \mathrm{RMB}$ per mu per season ${ }^{4}$. Since the government subsidizes $70 \%$ of the premium, households need to pay 3.6 RMB. If a farmer decides to buy the insurance, the premium is deducted from the rice production subsidy deposited annually in each farmer's bank account, with no cash payment needed $^{5}$. The policy stipulates that the policyholder is eligible to receive a payment if he/she experiences a $30 \%$ or greater yield loss due to any of the following reasons: heavy rain, floods, windstorms, extremely high or low temperatures, or drought. The loss rate in yield is determined through an investigation by a group of insurance agents and agricultural experts. The payout amount increases linearly with the loss rate in yield. The maximum insurance payout is $200 \mathrm{RMB}$, which covers at most $25 \%$ of the rice production income.

To illustrate this policy, let's consider the following example. Suppose the production income is $1000 \mathrm{RMB}$ per mu. The farmer can buy the insurance with $3.6 \mathrm{RMB} / \mathrm{mu}$. If a

\footnotetext{
${ }^{4} 1 \mathrm{RMB}=0.15$ USD; $1 \mathrm{mu}=0.165$ acre. Farmers produce two or three seasons of rice each year. The annual gross income per capita in the study region is around $5000 \mathrm{RMB}$.

${ }^{5}$ Starting in 2004, the Chinese government has given production subsidies to rice farmers in order to increase production incentives.
} 
wind disaster reduces this year's yield by $40 \%$, the farmer will receive $200 * 40 \%=80$ RMB per mu from the insurance company. Based on the estimation from the local weather station, the true probability of disaster is about 10\%. To make the take-up decision, a risk neutral farmer compares the expected payoff of not buying insurance $(0.9 * 1000+0.1 * 600=960)$ and that of buying insurance $(0.9 *(1000-3.6)+0.1 *(600-3.6+80)=964.4)$. Thus, a risk neutral subject who believes that the disaster risk is $10 \%$ or higher should buy the insurance.

The insurance product considered here differs from index-based weather insurance offered in other countries in several aspects. The product is actually a great deal for farmers, as the post-subsidy price is only around $1 \%$ of the production cost. Moreover, this product is more vulnerable to moral hazard as the payout is determined by loss in yield. However, the moral hazard problem should not be large here as the maximum payout (200 RMB) is much lower than the profit (800 RMB), and the product does require natural disasters to happen in order to trigger payouts.

\section{Experimental Design}

The experiment was conducted in the Summer of 2009 and the Spring of 2010 with a total of 885 households in Jiangxi province of China. The timeline for our experiment is presented in Figure 1. The experiment consists of two rounds of interviews for each household, with either one or three days between the two rounds. In round 1, the experimenters provide each household with a flyer detailing the information about the insurance contract. We then administer the baseline survey. After that, we randomly assign each household to one of four interventions, explained below. At the end of round 1, households are asked to think about 
whether they would like to buy the rice insurance, and are told that we will return in a few days to ask them what their purchase decision is. Then either one or three days later, we conduct a round 2 visit in which we ask farmers to indicate their purchase decisions and to sign the contract if they decided to buy the insurance.

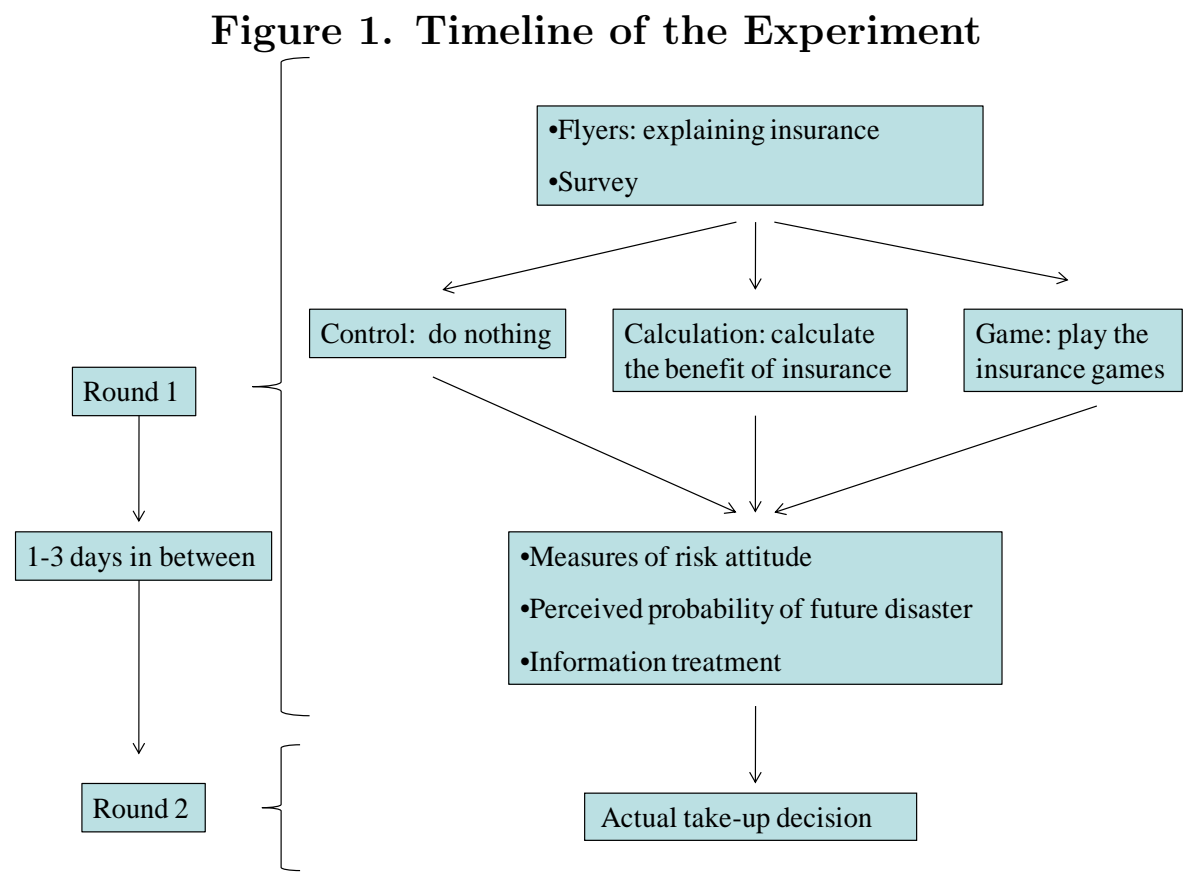

The experimental design is illustrated in Figure 2. The experiment has a 4 by 2 design. The first level of randomization consists of four groups that differ in how the insurance contract is explained to farmers. The second level of randomization consists of two groups that differ in whether we explicitly inform them about the true disaster probability ${ }^{6}$ To be consistent with the insurance policy design, "disaster" is defined as natural disasters including heavy rain, floods, windstorms, extremely high or low temperatures, or drought

\footnotetext{
${ }^{6}$ Before the randomization, we first approached the leaders of the villages and obtained a list that included the names and basic information about villagers. In our sample, we exclude households that do not grow rice. We also stratify the sample according to natural village, age of head of household, and total area of rice production. In each stratum, households are randomly assigned to one of the eight described interventions.
} 
that can cause at least $30 \%$ yield loss.

\section{Figure 2. Overview of Interventions}

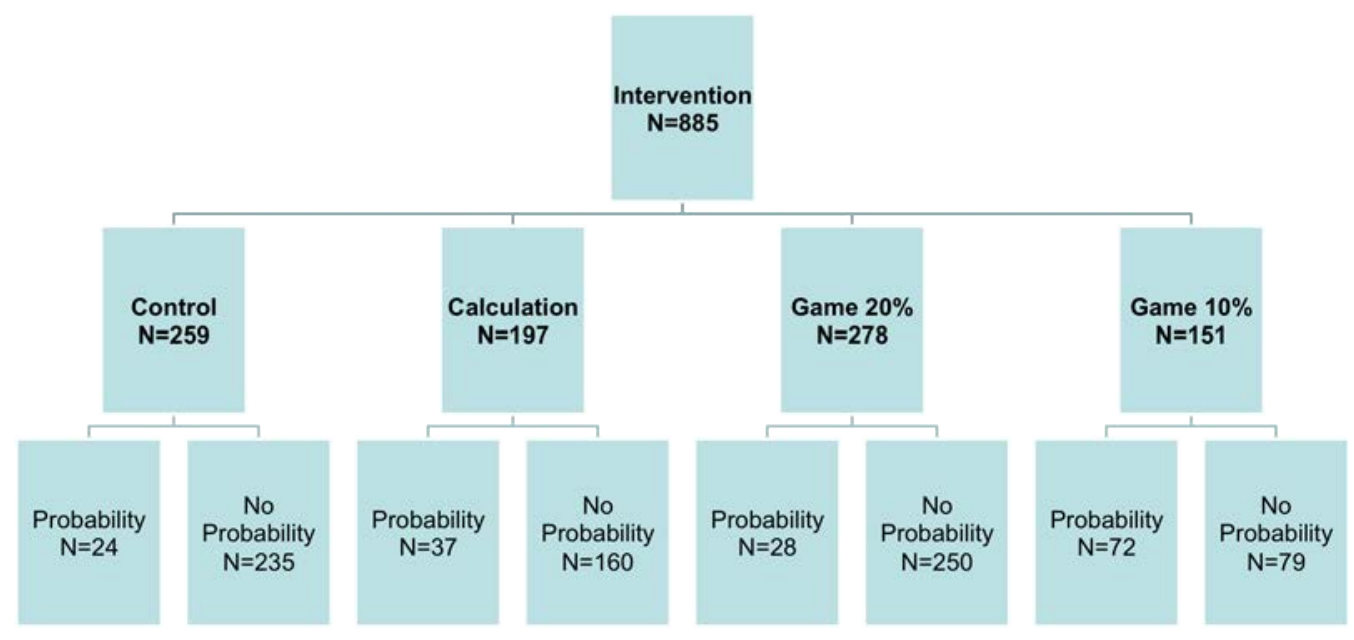

As mentioned, we randomly assign sample households into one of four intervention groups: the control group, the calculation group, the game 20\%-disaster-probability group, and the game 10\%-disaster-probability group. These interventions differ in how the insurance program is explained to the participants. We use two different disaster probabilities in the game treatment so that we can study insurance adoption behavior when the probability is either similar to or greater than the real disaster probability of $10 \%$. The detailed procedure for each group is as follows.

In the control group, the experimenters give each household a flyer with information about the rice insurance program and briefly explain the insurance contract. The household head is then asked to fill out a short survey regarding age, education, experience with insurance, experience with weather-related disasters, rice production, risk attitudes and perceptions of the probability of future weather disasters. 
In the calculation group, the experimenters follow the same procedure as for the control group, but also demonstrate how to calculate the expected payoff of buying/not buying insurance in the case of zero, one, two or three disasters occurring at any time in the next ten years. The details of the calculation examples provided to participants are illustrated in Table A1. In addition to demonstrating the calculations, the experimenters provide the following statement to each participant: "According to our calculations, if there is no large disaster in the next 10 years, it is better to not buy insurance in the following 10 years. If there is at least 1 disaster, it is better to always buy insurance in the following 10 years."

In the game $20 \%$ (respectively, 10\%) group, the experimenters follow the same procedure as for the control group before conducting the insurance game with the participant. The game includes ten rounds, representing the years 2011-2020, respectively, with the same procedure repeated in each round. Note that one difference between our study and most laboratory experiments is that our game is not incentivized; we pay all households in our study a flat fee to eliminate any confounding effects due to income effects. Compared with the calculation treatment, the game treatment explains the calculation of the expected payoff and also lets farmers explicitly experience hypothetical disasters. While the true probability of disaster is $10 \%$, we conduct a $20 \%$ game treatment as well to increase the variation in hypothetical experience during the game, and to study the interaction effect of the game and the probability treatment.

The following illustrates the structure of the game. The household head is first asked whether he or she would like to purchase insurance in the year 2011. After indicating this decision, the participant then plays a lottery which reveals whether a disaster occurs in that year. In the lottery, the participant is first shown a deck of ten cards face up to see how many cards contain a disaster. The participant then draws a card from the face down deck. After 
the lottery result is revealed, the experimenter and the participant calculate the income from that year based on the assumed expected income per acre plus any insurance payment (as shown in Table A2). The game is then played for another nine rounds ${ }^{7}$. At the end of the game, the participant receives the same statement as the calculation group ${ }^{8}$.

In a crossed randomization procedure, we randomize whether households are informed of the actual probability of a disaster at the end of round 1. The objective of providing this randomization is to help us test whether informing farmers about the true probability of disaster reduces uncertainty about the value of insurance and consequently increases the rate of insurance take-up. Interacting this randomization with how the contract is explained yields eight groups in total.

To study whether the intervention effects are due to changes in risk attitudes or perceptions of future disaster probabilities, we obtain information on these variables in round 1. For participants assigned to the game groups, we obtain this information after participants have played the insurance game, while for the calculation group, we obtain this information before the intervention. We elicit risk attitudes by asking participants to make a hypothetical choice between a sure amount of a monetary offer (riskless option A) and a risky gamble (risky option B). We use the number of riskless choices as a measure of risk aversion. The perceived probability of future disasters is elicited by asking participants the following question: "what do you think is the probability of a disaster that leads to a more than 30 percent yield loss next year?" To indicate their answers, participants are given 10 small paper balls and asked to distribute these paper balls across two areas: (1) no disaster resulting in yield

\footnotetext{
${ }^{7}$ Our experimental set-up would in expectation yield that $89 \%$ of participants in the game $20 \%$ group and $65 \%$ of the participants in the game $10 \%$ group are expected to experience at least one disaster across the 10 rounds of the game. The results indicate that $82 \%$ of households in the game $20 \%$ group and $66 \%$ of households in the game $10 \%$ group experience at least one disaster.

${ }^{8}$ As the game treatment takes longer than the calculation and control groups, we add some nonexperiment-related survey questions for the latter two groups to control for any time effect.
} 
loss of more than $30 \%$ for the next year and (2) a disaster resulting in yield loss of more than $30 \%$ for the next year. If a household puts 2 paper balls into (2) and 8 paper balls into (1), his perceived probability of future disaster is around $20 \%$.

To test whether the game treatment effects are due to changes in knowledge about insurance benefits, we obtain information regarding farmers' understanding of probability and insurance benefits prior to the treatment. For those participants assigned to either of the game groups, we obtain this information after they play the insurance game, while for the other groups, we obtain this information before the intervention. Specifically, to test their understanding of insurance benefits, we ask the following question: "Suppose your gross income is $1000 \mathrm{RMB}$ per mu, the loss from disaster is $400 \mathrm{RMB}$, insurance premium is 3.6 RMB, you get 80 RMB from insurance company if there is a disaster and you buy the insurance. What is your income per mu if there is a disaster but you did not buy insurance? What is your income per mu if there is a disaster and you bought the insurance?"

Table 1 reports the summary statistics and randomization check. We conduct our experiment in three waves. In the first wave, we included control and $20 \%$ probability game group. In the second wave, we further add the calculation group. In the third wave, we have eight groups in total, adding both the $10 \%$ probability game group and the probability treatment. Since we balance our randomization in each wave, the statistics in Figure 2 show a larger sample in the control and the $20 \%$ game group but a smaller sample in the calculation group, the $10 \%$ game group, and the probability group. 
Table 1. Summary Statistics and Randomization Check

\begin{tabular}{|c|c|c|c|c|c|c|c|c|c|c|c|c|}
\hline & \multicolumn{3}{|c|}{ Wave 1} & \multicolumn{4}{|c|}{ Wave 2} & \multicolumn{5}{|c|}{ Wave 3} \\
\hline & Control & $\begin{array}{c}\text { Game } \\
20 \% \\
\end{array}$ & $\overline{\text { p-value }}$ & Control & Calculation & $\begin{array}{l}\text { Game } \\
20 \%\end{array}$ & $\overline{\mathrm{p} \text {-value }}$ & Control & Calculation & $\begin{array}{c}\text { Game } \\
20 \% \\
\end{array}$ & $\begin{array}{c}\text { Game } \\
10 \% \\
\end{array}$ & p-value \\
\hline \multicolumn{13}{|l|}{$\begin{array}{l}\text { Panel A: Before } \\
\text { Playing the Game }\end{array}$} \\
\hline Age & $\begin{array}{c}46.90 \\
(11.33)\end{array}$ & $\begin{array}{c}50.44 \\
(12.37)\end{array}$ & 0.05 & $\begin{array}{c}51.43 \\
(11.41)\end{array}$ & $\begin{array}{c}50.86 \\
(11.67)\end{array}$ & $\begin{array}{c}52.99 \\
(12.32)\end{array}$ & 0.34 & $\begin{array}{c}50.64 \\
(12.28)\end{array}$ & $\begin{array}{c}48.27 \\
(11.47)\end{array}$ & $\begin{array}{l}52.10 \\
(12.24)\end{array}$ & $\begin{array}{c}48.53 \\
(12.17)\end{array}$ & 0.23 \\
\hline Education & $\begin{array}{l}1.38 \\
(0.75)\end{array}$ & $\begin{array}{c}1.32 \\
(0.82)\end{array}$ & 0.57 & $\begin{array}{c}1.30 \\
(0.78)\end{array}$ & $\begin{array}{c}1.30 \\
(0.71)\end{array}$ & $\begin{array}{l}1.35 \\
(0.82)\end{array}$ & 0.84 & $\begin{array}{l}1.45 \\
(0.78)\end{array}$ & $\begin{array}{c}1.37 \\
(0.85)\end{array}$ & $\begin{array}{l}1.41 \\
0.93)\end{array}$ & $\begin{array}{c}1.44 \\
(0.90)\end{array}$ & 0.94 \\
\hline Household Size & $\begin{array}{c}4.80 \\
(1.79)\end{array}$ & $\begin{array}{c}5.04 \\
(2.30)\end{array}$ & 0.62 & $\begin{array}{l}5.05 \\
(2.52)\end{array}$ & $\begin{array}{l}5.25 \\
(2.84)\end{array}$ & $\begin{array}{c}5.26 \\
(2.89)\end{array}$ & 0.80 & $\begin{array}{c}4.48 \\
(1.29)\end{array}$ & $\begin{array}{c}4.60 \\
(1.39)\end{array}$ & $\begin{array}{c}4.31 \\
(1.69)\end{array}$ & $\begin{array}{c}4.58 \\
(1.51)\end{array}$ & 0.75 \\
\hline $\begin{array}{l}\text { Area of Rice } \\
\text { Production }(\mathrm{mu})\end{array}$ & $\begin{array}{l}12.14 \\
(9.58)\end{array}$ & $\begin{array}{l}12.08 \\
(7.56)\end{array}$ & 0.97 & $\begin{array}{l}8.90 \\
(7.51)\end{array}$ & $\begin{array}{l}9.20 \\
(7.90)\end{array}$ & $\begin{array}{c}8.90 \\
(7.79)\end{array}$ & 0.94 & $\begin{array}{l}10.28 \\
(5.42)\end{array}$ & $\begin{array}{c}11.91 \\
(13.57)\end{array}$ & $\begin{array}{c}10.46 \\
(10.25)\end{array}$ & $\begin{array}{l}11.25 \\
(7.37)\end{array}$ & 0.69 \\
\hline $\begin{array}{l}\text { Share of Rice Income } \\
\text { in Total Income }(\%)\end{array}$ & $\begin{array}{c}84.00 \\
(21.16)\end{array}$ & $\begin{array}{c}85.05 \\
(24.19)\end{array}$ & 0.76 & $\begin{array}{l}64.30 \\
(28.2)\end{array}$ & $\begin{array}{c}63.13 \\
(27.07)\end{array}$ & $\begin{array}{c}60.24 \\
(28.04)\end{array}$ & 0.50 & $\begin{array}{c}90.8 \\
(14.79)\end{array}$ & $\begin{array}{c}89.45 \\
(15.58)\end{array}$ & $\begin{array}{c}87.34 \\
(18.70)\end{array}$ & $\begin{array}{c}87.38 \\
(16.99)\end{array}$ & 0.52 \\
\hline $\begin{array}{l}\text { Loss in Last Year (\%) } \\
\text { (self-report) }\end{array}$ & $\begin{array}{c}6.72 \\
(15.14)\end{array}$ & $\begin{array}{c}6.98 \\
(16.91)\end{array}$ & 0.92 & $\begin{array}{c}24.29 \\
(15.41)\end{array}$ & $\begin{array}{c}22.96 \\
(15.12)\end{array}$ & $\begin{array}{c}23.01 \\
(15.33)\end{array}$ & 0.79 & $\begin{array}{c}31.60 \\
(18.02)\end{array}$ & $\begin{array}{c}29.38 \\
(15.30)\end{array}$ & $\begin{array}{c}26.94 \\
(13.65)\end{array}$ & $\begin{array}{c}29.37 \\
(17.51)\end{array}$ & 0.53 \\
\hline $\begin{array}{l}\text { Self-Claim Positive } \\
\text { Trust Indicator }\end{array}$ & & & & $\begin{array}{c}0.22 \\
(0.42)\end{array}$ & $\begin{array}{c}0.18 \\
(0.39)\end{array}$ & $\begin{array}{c}0.16 \\
(0.37)\end{array}$ & 0.44 & $\begin{array}{c}0.56 \\
(0.50)\end{array}$ & $\begin{array}{c}0.44 \\
(0.50)\end{array}$ & $\begin{array}{c}0.47 \\
(0.50)\end{array}$ & $\begin{array}{c}0.37 \\
(0.48)\end{array}$ & 0.12 \\
\hline $\begin{array}{l}\text { Other-Claim Positive } \\
\text { Trust Indicator }\end{array}$ & & & & $\begin{array}{c}0.29 \\
(0.46)\end{array}$ & $\begin{array}{c}0.27 \\
(0.45)\end{array}$ & $\begin{array}{c}0.26 \\
(0.44)\end{array}$ & 0.90 & $\begin{array}{c}0.26 \\
(0.44)\end{array}$ & $\begin{array}{c}0.26 \\
(0.44)\end{array}$ & $\begin{array}{c}0.35 \\
(0.48)\end{array}$ & $\begin{array}{c}0.21 \\
(0.41)\end{array}$ & 0.35 \\
\hline \multicolumn{13}{|l|}{$\begin{array}{l}\text { Panel B: After } \\
\text { Playing the Game }\end{array}$} \\
\hline Risk Aversion & & & & $\begin{array}{c}4.13 \\
(1.45)\end{array}$ & $\begin{array}{c}4.16 \\
(1.44)\end{array}$ & $\begin{array}{c}4.10 \\
(1.43)\end{array}$ & 0.95 & $\begin{array}{c}3.20 \\
(1.52)\end{array}$ & $\begin{array}{c}3.23 \\
(1.44)\end{array}$ & $\begin{array}{c}3.04 \\
(1.59)\end{array}$ & $\begin{array}{c}3.11 \\
(1.71)\end{array}$ & 0.90 \\
\hline $\begin{array}{l}\text { Perceived Probability } \\
\text { of Future Disaster (\%) }\end{array}$ & & & & $\begin{array}{c}23.10 \\
(15.77)\end{array}$ & $\begin{array}{c}22.33 \\
(15.52)\end{array}$ & $\begin{array}{c}21.64 \\
(14.53)\end{array}$ & 0.76 & $\begin{array}{l}24.10 \\
(9.83)\end{array}$ & $\begin{array}{l}23.15 \\
(9.26)\end{array}$ & $\begin{array}{l}21.38 \\
(9.26)\end{array}$ & $\begin{array}{l}23.80 \\
(9.38)\end{array}$ & 0.30 \\
\hline Take-up $([0,1])$ & $\begin{array}{c}0.19 \\
(0.39) \\
\end{array}$ & $\begin{array}{c}0.24 \\
(0.43) \\
\end{array}$ & 0.42 & $\begin{array}{c}0.17 \\
(0.38) \\
\end{array}$ & $\begin{array}{c}0.17 \\
(0.38) \\
\end{array}$ & $\begin{array}{c}0.32 \\
(0.47) \\
\end{array}$ & 0.01 & $\begin{array}{c}0.28 \\
(0.45) \\
\end{array}$ & $\begin{array}{c}0.39 \\
(0.49) \\
\end{array}$ & $\begin{array}{c}0.37 \\
(0.49) \\
\end{array}$ & $\begin{array}{c}0.36 \\
(0.48) \\
\end{array}$ & 0.61 \\
\hline Observations & 86 & 95 & & 121 & 124 & 134 & & 52 & 73 & 49 & 151 & \\
\hline $\begin{array}{l}\text { Notes: This table presents } \\
\text { flyer with information ab } \\
\text { calculate the expected pay } \\
\text { the game } 20 \% \text { (respective } \\
\text { Education is coded as foll } \\
\text { dummy variable which eq } \\
\text { indicator is measured by }\end{array}$ & $\begin{array}{l}\text { sumr } \\
\text { the ric } \\
\text { of bu } \\
10 \%) \\
\text { s: } 0 \text {-ill } \\
\text { s one } \\
\text { ther a }\end{array}$ & $\begin{array}{l}\text { ary stati } \\
\text { insuran } \\
\text { ing/not } \\
\text { roup, we } \\
\text { eracy; } 1 \\
\text { a house } \\
\text { lousehol }\end{array}$ & $\begin{array}{l}\text { a hy } \\
\text { lary } \\
\text { has }\end{array}$ & $\begin{array}{l}\text { variables } \\
\text { and expl } \\
\text { ance if } z \\
\text { othetical } \\
\text { hool; } 2 \text {-s } \\
\text { eived a p } \\
\text { other vill }\end{array}$ & $\begin{array}{l}\text { and random } \\
\mathrm{n} \text { the insur: } \\
\text { o, one, two } \\
\text { surance ga } \\
\text { condary sch } \\
\text { yout from } \\
\text { gers receivi }\end{array}$ & $\begin{array}{l}\text { zation che } \\
\text { ce contrac } \\
\text { or three dis } \\
\text { le for } 10 \mathrm{r} \\
\text { ol; 3-high } \\
\text { other insu } \\
\text { g payouts }\end{array}$ & $\begin{array}{l}\text { ct briefl } \\
\text { sasters } \\
\text { ounds } \mathrm{y} \\
\text { school } \\
\text { urance c } \\
\text { from ot }\end{array}$ & $\begin{array}{l}\text { ontrol g } \\
\text { the ca } \\
\text { to occ } \\
\text { e there } \\
\text { ollege. } \\
\text { act and } \\
\text { insuran }\end{array}$ & $\begin{array}{l}\text { any time } \\
\text { two (resp } \\
\text {-claim tr } \\
\text { o otherwi } \\
\text { olicies. S }\end{array}$ & $\begin{array}{l}\text { ators g } \\
\text { e dem } \\
\text { he foll } \\
\text { ely, or } \\
\text { adicat } \\
\text { ther-c } \\
\text { ard de }\end{array}$ & $\begin{array}{l}\text { the hol } \\
\text { trate ho } \\
\text { ing ten } \\
\text { disaste } \\
\text { s define } \\
\text { n positi } \\
\text { tions ar }\end{array}$ & $\begin{array}{l}\text { old a } \\
\text { o } \\
\text { rs. In } \\
\text { a } \\
\text { rust } \\
\text { the }\end{array}$ \\
\hline
\end{tabular}

\section{Empirical Results}

In this section, we discuss the main empirical results. We firstly look at the impact of playing insurance games on real insurance take-up and explain the mechanisms of the effect. We then explain the effect of the probability treatment on insurance purchase. Lastly, we discuss the interaction effect of the game and probability treatment on insurance adoption. 


\subsection{The Impact of Game Treatment on Actual Insurance Take-up}

As shown in Figure 3, the insurance take-up rate for the control group is 19.8\%, while that of the calculation group is $24.7 \%$. By contrast, the take-up rate for the game group is $32.3 \%$. To see whether these effects are statistically significant, we run the following logit regression:

Figure 3. The Effect of Game and Calculation Treatments on Insurance Take-up

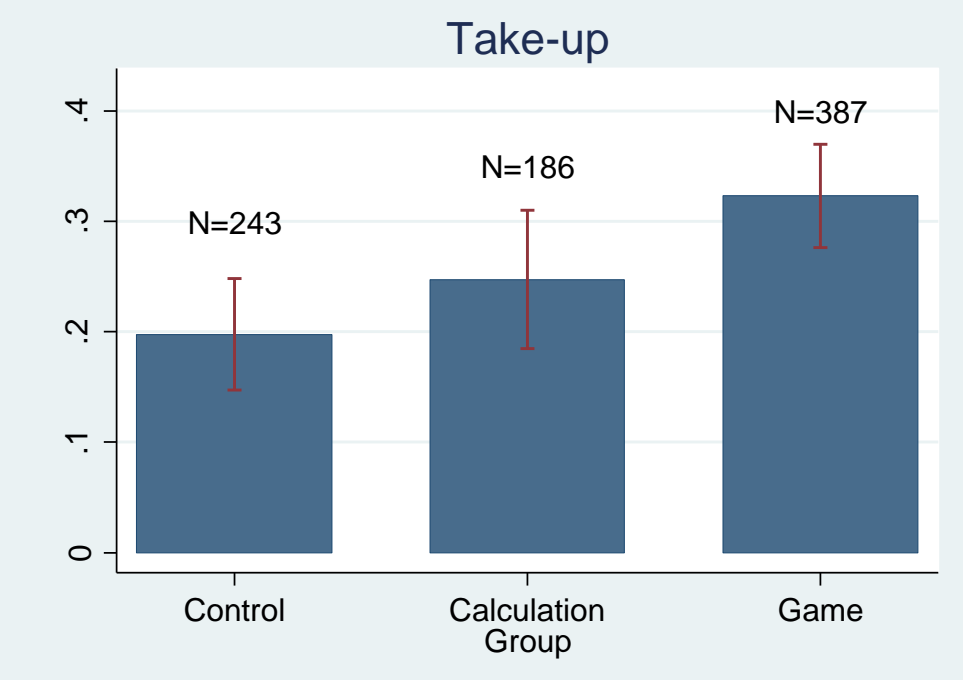

Notes: This figure shows the treatment effect for the calculation group and the game group, respectivley. In the control group, the take-up rate is $19.8 \%$. In the calculation group, the take-up rate increases to $24.7 \%$.In the game group, the take-up rate increases to $32.3 \%$. These results suggest that both the game treatment and the calculation treatment increase the actual take-up and the game treatment is more effective.

$$
b u y_{i j}=\alpha_{j}+\alpha_{k}+\beta_{g} T g_{i j}+\beta_{c} T c_{i j}+\phi X_{i j}+\epsilon_{i j}
$$

where $b u y_{i j}$ is an indicator that takes a value of one if household $i$ in natural village $j$ buys the insurance, $T g_{i j}$ is an indicator for the game treatment and $T c_{i j}$ is an indicator for the calculation treatment. $X_{i j}$ represent household head characteristics (e.g., gender, age, years 
of education, household size, area of production, car ownership, etc), and $\alpha_{j}$ and $\alpha_{k}$ represent village fixed effects and experimenter fixed effects, respectively. Since our roll-out design has three waves with different set of villages, including village fixed effects in the regression explicitly controlls for wave fixed effects.

We report the marginal effects of our main interventions in Table 2. The results in column (1) show that the marginal effect of the game treatment (0.091) is positive and significant at the $5 \%$ level, while the marginal effect of the calculation treatment (0.024) is insignificantly positive. This means that participating in the insurance game increases insurance take-up by 9.1 percentage points, representing a $46 \%$ increase relative to the baseline take-up rate of $20 \%^{9}$. In column (2), we present the results of the game treatment separately for the 10 and $20 \%$ groups. These results show that the effect of the game treatment on insurance take-up is higher, albeit insignificantly, for the $20 \%$ game group compared to the $10 \%$ game group. We discuss these findings in greater detail in Section 4.2.3.

To further explain the magnitude of the game effect, we compare our results with the impact of real experiences of disasters on insurance take-up. The results in column (3) of Table 2 show that the game effect on insurance take-up is equivalent to the effect of a 42 percentage point increase in actual yield loss in the previous year. Column (4) presents the results when we add household characteristics to the estimation; these results are similar.

We next test the heterogeneity of the game treatment effect. Results presented in Table 3 show that the magnitude of the game effect does not change with participant age, education, household size, production scale, or the perceived probability of disasters.

\footnotetext{
${ }^{9}$ Since there is a period of one to three days between the intervention and the decision-making, there might be spillover effects the insurance take-up rate. Thus, our estimated treatment effects are likely to reflect a lower bound relative to true treatment effects.
} 
Table 2. The Effect of Game Treatment on Insurance Take-up

\begin{tabular}{|c|c|c|c|c|}
\hline \multirow{4}{*}{$\begin{array}{l}\text { Specification: } \\
\text { Dep. Var.: } \\
\text { Sample: }\end{array}$} & \multicolumn{4}{|c|}{ Logistic regression } \\
\hline & \multicolumn{4}{|c|}{ Individual Adoption of Insurance } \\
\hline & \multicolumn{4}{|c|}{ All Sample } \\
\hline & $(1)$ & (2) & (3) & (4) \\
\hline Game $(1=$ Yes, $0=$ No $)$ & $\begin{array}{c}0.091 \\
(0.039)^{* *}\end{array}$ & & $\begin{array}{c}0.096 \\
(0.037)^{* * *}\end{array}$ & $\begin{array}{c}0.092 \\
(0.038)^{* *}\end{array}$ \\
\hline Calculation $(1=$ Yes, $0=\mathrm{No})$ & $\begin{array}{c}0.024 \\
(0.044)\end{array}$ & $\begin{array}{c}0.019 \\
(0.045)\end{array}$ & $\begin{array}{c}0.028 \\
(0.043)\end{array}$ & $\begin{array}{c}0.030 \\
(0.041)\end{array}$ \\
\hline Game $20 \%(1=$ Yes, $0=$ No $)$ & & $\begin{array}{c}0.107 \\
(0.035)^{* * *}\end{array}$ & & \\
\hline Game $10 \%(1=$ Yes, $0=$ No $)$ & & $\begin{array}{c}0.047 \\
(0.067)\end{array}$ & & \\
\hline Probability $(1=$ Yes, $0=\mathrm{No})$ & $\begin{array}{c}0.043 \\
(0.050)\end{array}$ & $\begin{array}{c}0.039 \\
(0.050)\end{array}$ & $\begin{array}{c}0.050 \\
(0.051)\end{array}$ & $\begin{array}{c}0.046 \\
(0.049)\end{array}$ \\
\hline \%Loss Last Year (self report) & & & $\begin{array}{c}0.216 \\
(0.100)^{* *}\end{array}$ & $\begin{array}{c}0.208 \\
(0.106)^{* *}\end{array}$ \\
\hline Age & & & & $\begin{array}{c}0.009 \\
(0.011)\end{array}$ \\
\hline Education & & & & $\begin{array}{c}0.039 \\
(0.018)^{* *}\end{array}$ \\
\hline Household Size & & & & $\begin{array}{c}-0.015 \\
(0.005)^{* * *}\end{array}$ \\
\hline Area of Rice Production (mu) & & & & $\begin{array}{c}0.0015 \\
(0.0138) \\
\end{array}$ \\
\hline Wald Test: & $\beta g=\beta c$ & $\beta_{20}=\beta_{10}$ & $\beta g=\beta c$ & $\beta g=\beta c$ \\
\hline p-value & 0.1333 & 0.2911 & 0.1262 & 0.1474 \\
\hline Obs. & 816 & 816 & 816 & 816 \\
\hline Omitted Treatment & \multicolumn{4}{|c|}{ Control } \\
\hline $\begin{array}{l}\text { Mean of Dep. Var. for Omitted } \\
\text { Treatment: }\end{array}$ & \multicolumn{4}{|c|}{0.198} \\
\hline $\begin{array}{l}\text { Fixed Effects for Village and } \\
\text { Enumerator }\end{array}$ & Y & Y & Y & Y \\
\hline Log Likelihood & -430.63 & -429.97 & -428.34 & -423.56 \\
\hline Pseudo R-square & 0.0927 & 0.0941 & 0.0975 & 0.1076 \\
\hline \multicolumn{5}{|c|}{$\begin{array}{l}\text { Notes: This table tests the effect of the game and calculation treatments on real insurance take-up using all } \\
\text { study sample. In the calculation treatment, we demonstrate how to calculate the expected payoff of } \\
\text { buying/not buying insurance if zero, one, two or three disasters were to occur at any time in the following } \\
\text { ten years. In the game } 20 \% \text { (respectively, } 10 \% \text { ) treatment, we play a hypothetical insurance game for } 10 \\
\text { rounds where there are two (respectively, one) disasters. In the probability treatment, households were } \\
\text { informed of the actual probability of disaster. Column (2) compares take-up between the two game groups } \\
\text { with } 20 \% \text { and } 10 \% \text { probability of disasters. In column (3), the self reported percentage of loss in last year } \\
\text { is included in the regression. In column (4), additional control variables are added, including age and } \\
\text { education of household head, household size, and area of rice production. Standard errors are clustered by } \\
16 \text { natural villages. Robust clustered standard errors are in the parentheses. *** significant at } 1 \% \text { level; } * * \\
\text { significant at } 5 \% \text { level; * significant at } 10 \% \text { level. }\end{array}$} \\
\hline
\end{tabular}


Table 3. The Heterogeneity of the Game Effect on Insurance Take-up

\begin{tabular}{|c|c|c|c|c|c|c|}
\hline \multirow{4}{*}{$\begin{array}{l}\text { Specification: } \\
\text { Dep. Var.: } \\
\text { Sample }\end{array}$} & \multicolumn{6}{|c|}{ Logistic Regression } \\
\hline & \multicolumn{6}{|c|}{ Individual Adoption of Insurance } \\
\hline & \multicolumn{6}{|c|}{ All Sample } \\
\hline & $(1)$ & $(2)$ & (3) & $(4)$ & $(5)$ & $(6)$ \\
\hline \multirow[t]{2}{*}{ Game (1=Yes, $0=$ No $)$} & 0.141 & 0.0279 & 0.108 & 0.195 & 0.0765 & 0.068 \\
\hline & $(0.0703)^{* *}$ & -0.0465 & $(0.0644)^{*}$ & $(0.0920)^{* *}$ & -0.0543 & $(0.0312)^{* *}$ \\
\hline \multirow[t]{2}{*}{ Calculation $(1=$ Yes, $0=$ No) } & 0.0275 & 0.0264 & 0.027 & 0.0277 & 0.0292 & 0.0318 \\
\hline & $(0.0419)$ & $(0.042)$ & $(0.0417)$ & $(0.0415)$ & $(0.043)$ & $(0.0431)$ \\
\hline \multirow[t]{2}{*}{ Game $\times$ Age } & -0.0211 & & & & & \\
\hline & $(0.0185)$ & & & & & \\
\hline \multirow[t]{2}{*}{ Game $\times$ Education } & & 0.0419 & & & & \\
\hline & & $(0.0306)$ & & & & \\
\hline \multirow[t]{2}{*}{ Game $\times$ Household Size } & & & -0.00741 & & & \\
\hline & & & $(0.0155)$ & & & \\
\hline \multirow[t]{2}{*}{ Game $\times$ Area of Rice Production $(\mathrm{mu})$} & & & & -0.0292 & & \\
\hline & & & & $(0.0211)$ & & \\
\hline \multirow[t]{2}{*}{ Game $\times \%$ Loss Last Year } & & & & & 0.0589 & \\
\hline & & & & & $(0.15)$ & \\
\hline Game $\times$ & & & & & & 0.0122 \\
\hline Perceived Probability of Future Disaster & & & & & & $(0.0107)$ \\
\hline Obs. & 816 & 816 & 816 & 816 & 816 & 816 \\
\hline \multirow{2}{*}{$\begin{array}{l}\text { Omitted Treatment } \\
\text { Mean of Dep. Var. for Omitted Treatment: }\end{array}$} & \multicolumn{6}{|c|}{ Control } \\
\hline & \multicolumn{6}{|c|}{0.198} \\
\hline Social-economic Variables & $\mathrm{Y}$ & $\mathrm{Y}$ & $\mathrm{Y}$ & $\mathrm{Y}$ & Y & Y \\
\hline Fixed effects for village and enumerator & $\mathrm{Y}$ & $\mathrm{Y}$ & $\mathrm{Y}$ & $\mathrm{Y}$ & $\mathrm{Y}$ & $\mathrm{Y}$ \\
\hline Log Likelihood & -425.63 & -425.31 & -425.93 & -424.76 & -425.84 & -425.73 \\
\hline Pseudo R-square & 0.1032 & 0.1039 & 0.1026 & 0.1050 & 0.1028 & 0.1030 \\
\hline
\end{tabular}

\subsection{Mechanisms Driving the Game Effect on Insurance Take-Up}

In this study, we consider three possible mechanisms that may drive the observed game intervention effect: (1) changes in risk attitudes or the perceived probability of future disasters, (2) improved knowledge about the benefits of insurance, and (3) changes in hypothetical experience with disasters. In this section, we consider each mechanism in turn. 


\subsubsection{Changes in Risk Attitudes and the Perceived Probability of Future Dis- aster}

First, to test the possibility that the game increases insurance adoption because it changes participants' attitudes toward risk, we ask whether the game treatment can change people's risk attitudes to the extent that it can generate an impact on insurance take-up that is as large as the game effect. To do so, we estimate the following regression system:

$$
\begin{gathered}
\text { buy }_{i j}=\alpha_{j}+\alpha_{k}+\beta_{\text {risk }} \text { risk }_{i j}+\beta_{\text {prob }} \text { rrob }_{i j}+\phi X_{i j}+\delta_{i j} \\
\text { risk }_{i j}=\alpha_{j}+\alpha_{k}+\gamma_{g r} T g_{i j}+\gamma_{c r} T c_{i j}+\phi X_{i j}+\eta_{i j} \\
\text { risk }_{i j}=\alpha_{j}+\alpha_{k}+\beta_{d r} \text { disaster }_{i j}+\phi X_{i j}+\omega_{i j}
\end{gathered}
$$

where risk $_{i j}$ is a measure of risk aversion and disaster $i j$ is the number of hypothetical disasters that a participant experiences during the game. Equation (2) represents the correlation between insurance take-up and risk attitudes. We restrict the sample in equation (2) to the control and calculation groups, as these are the groups that receive a pre-intervention survey on their risk attitudes. In equations (3) and (4), we estimate the effects of the insurance game and disaster experiences in the game, respectively. We apply a seemingly unrelated regression (SUR) model to estimate equations (2), (3) and (4). This allows us to account for any correlation of error terms between equations.

We present the results in Table 4. The results in column (1) indicate significantly positive coefficients for both risk aversion (0.035) and the perceived probability of future disasters (0.215). Column (2) presents estimates for equation (3), including various controls and dummies for missing values, while column (3) presents the results when we restrict our 
Table 4. The Decomposition of the Game Effect: Changes in Risk Aversion and Perceived Probability of Future Disasters

\begin{tabular}{|c|c|c|c|c|c|c|c|}
\hline Specification: & & & & Regressi & & & \\
\hline Dep. Var:: & $\begin{array}{c}\text { Individual } \\
\text { Adoption of } \\
\text { Insurance } \\
\end{array}$ & & k Aversi & & Perceived & $\begin{array}{l}\text { Probability } \\
\text { Disaster }\end{array}$ & of Future \\
\hline Sample: & $\begin{array}{l}\text { Control \& } \\
\text { Calculation }\end{array}$ & All Sample & (3) & (4) & All Sample & (6) ${ }^{\mathrm{G}}$ & (7) \\
\hline$\overline{\text { Game (1=Yes, } 0=\text { No) }}$ & & $\begin{array}{l}-0.0237 \\
(0.182)\end{array}$ & & & $\begin{array}{c}-0.0152 \\
(0.00755) *\end{array}$ & & \\
\hline Calculation $(1=$ Yes, $0=\mathrm{No})$ & & $\begin{array}{l}0.0553 \\
(0.165)\end{array}$ & & & $\begin{array}{c}-0.0111 \\
(0.00943)\end{array}$ & & \\
\hline Risk Aversion & $\begin{array}{c}0.0348 \\
(0.0160)^{* *}\end{array}$ & & & & & & \\
\hline $\begin{array}{l}\text { Perceived Probability of Future } \\
\text { Disaster }\end{array}$ & $\begin{array}{c}0.215 \\
(0.110)^{*}\end{array}$ & & & & & & \\
\hline Number of Hypothetical Disasters & & & $\begin{array}{l}0.0799 \\
(0.138)\end{array}$ & & & $\begin{array}{c}0.00297 \\
(0.00759)\end{array}$ & \\
\hline $\begin{array}{l}\text { Number of Game Rounds with } \\
\text { Insurance Purchase and Draw a } \\
\text { Disaster }\end{array}$ & & & & 0.0975 & & & -0.0027 \\
\hline & & & & $(0.0678)$ & & & $(0.0077)$ \\
\hline $\begin{array}{l}\text { Number of Game Rounds with No } \\
\text { Insurance Purchase and Draw a } \\
\text { Disaster }\end{array}$ & & & & -0.0493 & & & 0.0232 \\
\hline & & & & $(0.1228)$ & & & $(0.0183)$ \\
\hline $\begin{array}{l}\text { Number of Game Rounds with No } \\
\text { Insurance and No Disaster }\end{array}$ & & & & 0.0464 & & & -0.0090 \\
\hline & & & & $(0.0384)$ & & & $(0.0039) * *$ \\
\hline $\begin{array}{l}\text { Obs. } \\
\text { Omitted Treatment }\end{array}$ & 329 & 697 & 320 & 320 & 667 & 310 & 310 \\
\hline $\begin{array}{l}\text { Mean of Dep. Var. for Omitted } \\
\text { Treatment: }\end{array}$ & & & & $\begin{array}{l}\text { Control } \\
0.198\end{array}$ & & & \\
\hline Social-economic Variables & Y & $\mathrm{Y}$ & Y & Y & $\mathrm{Y}$ & Y & $\mathrm{Y}$ \\
\hline $\begin{array}{l}\text { Fixed Effects for Village and } \\
\text { Enumerator }\end{array}$ & $\mathrm{Y}$ & $\mathrm{Y}$ & $\mathrm{Y}$ & $\mathrm{Y}$ & $\mathrm{Y}$ & $\mathrm{Y}$ & $\mathrm{Y}$ \\
\hline R-square & 0.1397 & 0.1932 & 0.2022 & 0.2068 & 0.0990 & 0.1896 & 0.2140 \\
\hline
\end{tabular}

Notes: This table tests changes in risk aversion and perceived probability of future disasters as mechanisms of the game intervention. In column (1), we restrict the sample to the control group and the calculation group and tests the impact of risk aversion and perceived probability of future disasters on insurance take-up. In columns (2) to (4), we regress risk aversion indicator on treatment indicators and controls. In columns (5) to (7), we regress the perceived probability of future disasters on treatment indicators and controls. Standard errors are clustered by 16 natural villages. Robust clustered standard errors are in the parentheses. *** significant on $1 \%$ level; ** significant on $5 \%$ level, * significant on $10 \%$ level.

sample to only the set of participants in the game treatment groups. We then test the following two hypotheses:

$$
\begin{gathered}
\beta_{\text {risk }} \gamma_{g r}=\beta_{g} \\
1.48 \beta_{\text {risk }} \gamma_{g r}=\beta_{g}{ }^{10}
\end{gathered}
$$

\footnotetext{
${ }^{10} 1.48$ is average number of hypothetical disasters people experienced during the games.
} 
The first hypothesis is rejected at the $5 \%$ level $(\mathrm{p}=0.024)$, with a $95 \%$ confidence interval in $[-0.012,0.010]$, while the second hypothesis is also rejected at the $5 \%$ level $(\mathrm{p}=0.028)$, with a $95 \%$ confidence interval of $1.48 \beta_{\text {risk }} \gamma_{g r}$ ranging in $[-0.003,0.004]$. Overall, these results suggest that changes in risk attitudes are unlikely to explain the game effect ${ }^{11}$.

We next use a similar strategy to examine whether an increased perceived probability of future disasters drives our main effect. The results in Table 4, column (5) indicate that the game treatment has an overall negative effect on the perceived probability of future disasters. We further see that the coefficient for the number of hypothetical disasters is not significant (column (6)). As a result, we conclude that changes in the perceived probability of future disasters are unlikely to explain the game treatment effect.

Examining the finding that the game treatment actually reduces the perceived probability of future disasters, we look more closely at the experiences our participants have during the game. Specifically, we examine the following four types of experiences: not buy insurance and draw a disaster, not buy insurance and experience no disaster, buy insurance and draw a disaster, buy insurance and experience no disaster. Examining these groups, we find that the marginally significant negative effect of the game treatment on perceived probability is mainly driven by participants who have more rounds of not buying insurance and experiencing no disasters (column (7), Table 4). This group likely anchors on the low probability of disasters experienced during the game in determining their perceived probability of disaster.

\footnotetext{
${ }^{11}$ Note that we do not assume a lack of measurement error. Rather, we assume that there is no differential measurement error between the control and the treatment groups. Since subjects are randomly assigned to different groups, any measurement error is likely to be the same across different treatment groups.
} 


\subsubsection{Changes in Knowledge Regarding the Benefits of Insurance}

We next consider whether the game effect is driven by improvements in knowledge about the benefits of insurance. We use three strategies to test this channel.

First, we compare the effects of the game and calculation treatments. If learning about insurance benefits is the main driver behind the game effect, then we should see no significant difference in insurance take-up between the game and calculation treatments, as each provides the same information about insurance benefits. Here, we find that the calculation treatment effect is statistically insignificant, resulting in an increased take-up of 2.4 percentage points.

Second, we include post-treatment survey questions to test whether the game treatment improves knowledge of insurance benefits. The results in columns (1) and (4) in Table 5 show that the coefficients for the game treatment are small and insignificant. However, it is still possible that the subset of farmers who experience more disasters during the game might learn more about the insurance benefits. Consequently, we test whether the number of hypothetical disasters has an impact on insurance knowledge. The results in columns (2) and (5) show that the coefficient for the Number of Hypothetical Disasters is slightly negative and insignificant ${ }^{12}$. Finally, we examine whether insurance knowledge obtained during the game is different for groups with different hypothetical experiences. Using the four types of experience outlined in section 4.2.1, we consider whether participants learn more about insurance benefits if they do not buy insurance in the game yet draw a disaster. It is possible

\footnotetext{
${ }^{12}$ We consider the level of complexity for our questions that test insurance knowledge. First, our control group is able to provide $41.6 \%$ correct answers for insurance question 1 and $26.5 \%$ correct answers for insurance question 2 (Table 5). Furthermore, we test the interaction effect between our game treatment and the level of participant education. If our questions are complex, those with a higher education level should demonstrate a bigger effect of the game treatment on insurance knowledge. However, our results in columns (1) and (2) of Table A3 show that the coefficient for the interaction between game treatment and education is negative and insignificant. As a result, we conclude that our questions are not too complicated for farmers to answer.
} 
Table 5. The Effect of Game Treatment on Insurance Knowledge

\begin{tabular}{|c|c|c|c|c|c|c|}
\hline \multirow{4}{*}{$\begin{array}{l}\text { Specification: } \\
\text { Sample } \\
\text { Dep. Var.: }\end{array}$} & \multicolumn{6}{|c|}{ OLS Regression } \\
\hline & \multicolumn{6}{|c|}{ All Sample } \\
\hline & \multicolumn{3}{|c|}{ Insurance Benefit Question 1} & \multicolumn{3}{|c|}{ Insurance Benefit Question 2} \\
\hline & (1) & (2) & (3) & (4) & $(5)$ & $(6)$ \\
\hline Game (1=Yes, $0=$ No) & $\begin{array}{c}0.00879 \\
(0.00975)\end{array}$ & $\begin{array}{c}0.031 \\
(0.0241)\end{array}$ & $\begin{array}{c}0.0163 \\
(0.0140)\end{array}$ & $\begin{array}{c}0.0158 \\
(0.0219)\end{array}$ & $\begin{array}{c}0.0248 \\
(0.0232)\end{array}$ & $\begin{array}{c}0.0126 \\
(0.0214)\end{array}$ \\
\hline$\%$ Loss Last Year (self report) & $\begin{array}{l}-0.102 \\
(0.0807)\end{array}$ & & & $\begin{array}{c}0.0385 \\
(0.0636)\end{array}$ & & \\
\hline Number of Hypothetical Disasters & & $\begin{array}{l}-0.0176 \\
(0.0177)\end{array}$ & & & $\begin{array}{c}-0.0092 \\
(0.00841)\end{array}$ & \\
\hline \multirow[t]{2}{*}{$\begin{array}{l}\text { Number of Game Rounds with } \\
\text { Insurance Purchase and Draw a } \\
\text { Disaster }\end{array}$} & & & -0.0084 & & & -0.0001 \\
\hline & & & $(0.0056)$ & & & $(0.0029)$ \\
\hline \multirow[t]{2}{*}{$\begin{array}{l}\text { Number of Game Rounds with No } \\
\text { Insurance Purchase and Draw a } \\
\text { Disaster }\end{array}$} & & & -0.0315 & & & -0.0446 \\
\hline & & & $(0.0296)$ & & & $(0.0526)$ \\
\hline \multirow[t]{2}{*}{$\begin{array}{l}\text { Number of Game Rounds with No } \\
\text { Insurance and No Disaster }\end{array}$} & & & 0.0071 & & & 0.0082 \\
\hline & & & $(0.0076)$ & & & $(0.0074)$ \\
\hline Obs. & 658 & 650 & 650 & 657 & 649 & 649 \\
\hline Omitted Treatment & \multicolumn{6}{|c|}{ Control } \\
\hline $\begin{array}{l}\text { Mean of Dep. Var. for Omitted } \\
\text { Treatment: }\end{array}$ & \multicolumn{3}{|c|}{0.416} & \multicolumn{3}{|c|}{0.265} \\
\hline Social-economic Variables & $\mathrm{Y}$ & $\mathrm{Y}$ & $\mathrm{Y}$ & $\mathrm{Y}$ & $\mathrm{Y}$ & $\mathrm{Y}$ \\
\hline $\begin{array}{l}\text { Fixed effects for village and } \\
\text { enumerator }\end{array}$ & $\mathrm{Y}$ & $\mathrm{Y}$ & $\mathrm{Y}$ & $\mathrm{Y}$ & $\mathrm{Y}$ & $\mathrm{Y}$ \\
\hline R-square & 0.7692 & 0.7589 & 0.7594 & 0.6882 & 0.6757 & 0.6765 \\
\hline \multicolumn{7}{|c|}{$\begin{array}{l}\text { Notes: This table tests the effect of the game treatment on insurance knowledge test result based on the whole study } \\
\text { sample. Insurance Benefit Question } 1 \text { is "Suppose your gross income is } 1000 \text { RMB per mu, the loss from disaster is } \\
400 \text { RMB, insurance premium is } 3.6 \text { RMB, you get } 80 \text { RMB from insurance company if there is a disaster and you } \\
\text { buy the insurance. What is your income per mu if there is a disaster but you did not buy insurance? " Insurance } \\
\text { Benefit Question } 2 \text { is "What is your income per mu if there is a disaster and you bought the insurance?" In column } \\
\text { (3) and (6), we test the impact of four types of game experience on insurance knowledge: buy insurance and draw a } \\
\text { disaster, buy insurance and experience no disaster (omitted), not buy insurance and draw a disaster, and not buy } \\
\text { insurance and experience no disaster. Standard errors are clustered by } 16 \text { natural villages. Robust clustered standard } \\
\text { errors are in the bracket;*** significant on } 1 \% \text { level, ** significant on } 5 \% \text { level, * significant on } 10 \% \text { level. }\end{array}$} \\
\hline
\end{tabular}

that this negative experience may draw more attention to the income and insurance benefits calculation. Our results in columns (3) and (6) of Table 5 show that the level of insurance knowledge does not vary with the number of negative outcomes experienced during the game. Thus, we conclude that an increase in knowledge of insurance benefits does not drive our 
main result ${ }^{13}$.

\subsubsection{Changes in Hypothetical Experience}

The final explanation that we consider is that the hypothetical experience gained during the game is the driver behind the effect of the game on insurance adoption. To test this hypothesis, we take advantage of the exogenous variation of the number of hypothetical disasters during the game and test the effect of that on real insurance purchase decisions. We present the results in column (1) of Table 6. The coefficient (0.059) is positive and statistically significant at the $10 \%$ level.

Again, we use our four groups of game experiences to analyze the relationship between the number of rounds with each type of experience and real insurance take-up rates. The results in column (2) of Table 6 show that experiencing one more round of not buying insurance and drawing a disaster increases real insurance take-up by 5.4 percentage points, while experiencing one more round of not buying insurance and not drawing a disaster reduces real insurance take-up by 1.6 percentage points. These results suggest that one possible explanation of the effect of hypothetical disaster experience on insurance take-up is that, simulated experiences during the game improve the salience of disasters to farmers and, as a result, increase their insurance take-up.

We next explore the effect of disaster experience on insurance take-up when participants

experience a disaster in the first five vs. last five rounds of the game. Figure 4 outlines the 
Table 6. The Effect of the Number of Hypothetical Disasters on Real Insurance Take-up

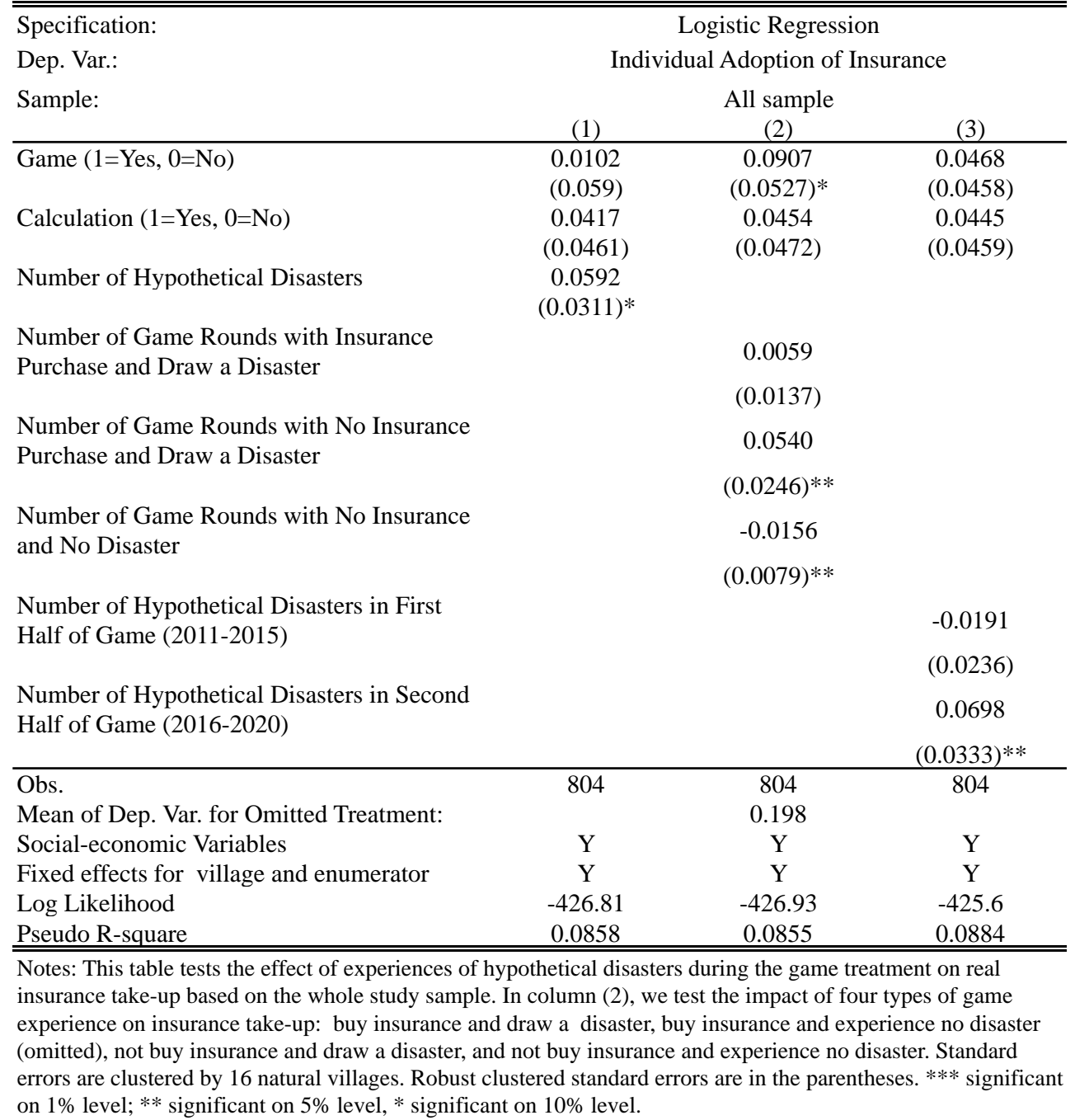

\section{insurance take-up rate across different treatment groups.}

\section{We analyze the relation between disaster timing and insurance take-up using the following}

\footnotetext{
${ }^{13}$ Another strategy we use to rule out the knowledge mechanism is to test whether the game treatment increases the probability that subjects provide a concrete answer rather than "I do not know" when answering the insurance questions. If people learn knowledge from the game treatment, they should be more confident in answering the question. However, the results in columns (3) and (4) in Table A3 show that there is no effect of the game treatment on the probability that subjects provide a concrete answer.
} 


\section{Figure 4. Take-up by Treatment Groups}

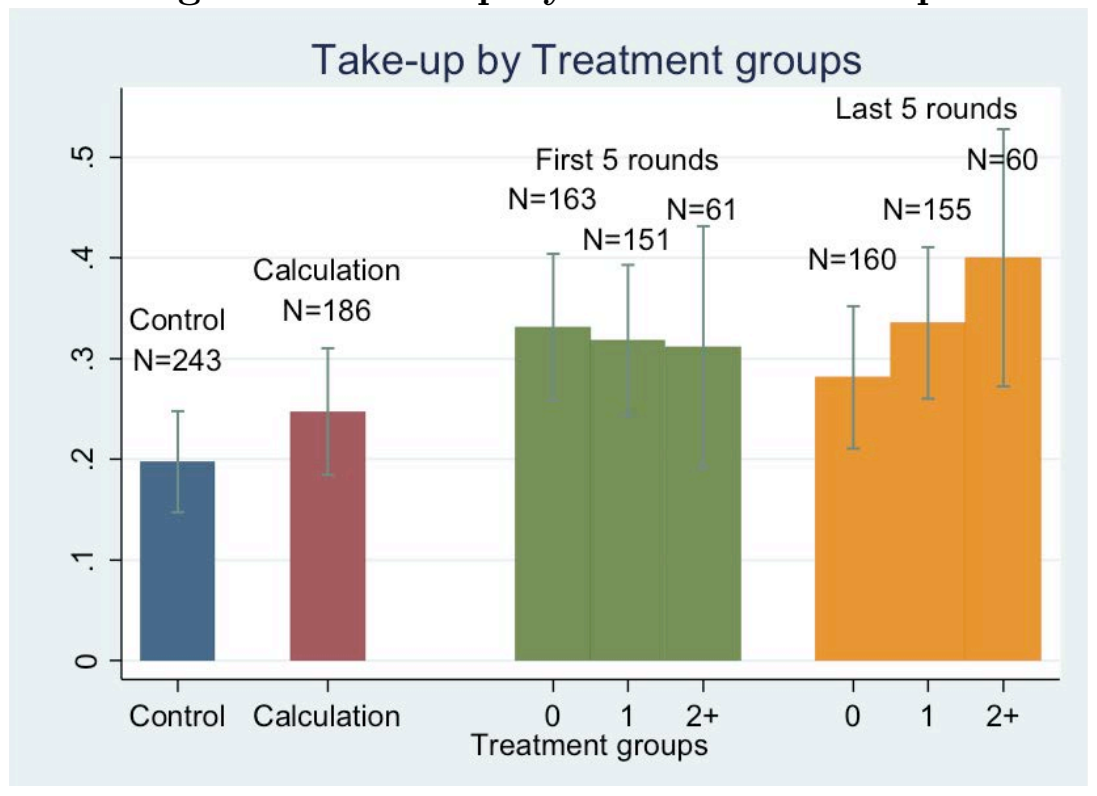

Notes: This figure shows the insurance take-up by treatment groups. The left two bars show insurance take-up in the Control and the Calculation treatment. The right two bars show insurance take-up conditional on the number of disasters in the first five rounds and last five rounds.

regression:

$$
\text { buy }_{i j}=\alpha_{j}+\alpha_{k}+\gamma_{g r} T g_{i j}+\gamma_{c r} T c_{i j}+\beta_{f 5} \text { disasterfirst } 5_{i j}+\beta_{15} \text { disasterlast }_{i j}+\delta_{i j}
$$

As seen in column (3) of Table 6, the coefficient for "disaster experience in the first half of the game" is negative and insignificant. By contrast, the coefficient for "disaster experience in the last half of the game" is positive and significant at the $5 \%$ level. This latter coefficient suggests that experiencing an additional disaster in the last half of the game increases insurance take-up by 7.0 percentage points ${ }^{14}$. Furthermore, if we regress insurance take-up on the number of hypothetical disasters in the first (10- $n$ ) rounds and that in the last $\mathrm{n}$ rounds,

\footnotetext{
${ }^{14} \mathrm{We}$ also investigate the relation between disaster timing and hypothetical insurance take-up decisions during the game. For details, refer to Appendix C.
} 
we find that, when $\mathrm{n}$ equals $5,6,7,8$ or 9 , the coefficients for the last $\mathrm{n}$ rounds are all positive and significant at the $5 \%$ level (Table A4) ${ }^{15}$.

Overall, our results regarding the timing of when participants experience a disaster in the game are consistent with the "recency effect" defined in the existing literature (Fredrickson and Kahneman (1993) Schreiber and Kahneman (2000); Erev and Haruvy (2013)). This literature has demonstrated that the experience during the final moments of a lab experiment impacts subsequent evaluations, and participants assign greater weight to the latter moments in an experiment. Although the length of these experiments is generally short, recent research provides consistent evidence that the latter moments also impact long-term individual behavior. For example, Haisley and Loewenstein (2011) find that, given the same total gift value, those who receive a gift with a low value in the last round of an experiment have a much lower deposit balance five months after the experiment than those who receive a gift with a high value in the last round of the experiment. Healy and Lenz (2014) show that voters respond primarily to the election-year economy when making their choices; and Karlan et al. (2014a) documents that farmers are more likely to buy weather-index insurance if they recently experienced disasters and payouts.

Examining the recency effect, we consider three possible explanations. First, memory may decrease over time. However, the brief nature of our games suggests that this is not a likely channel. Second, recent experiences of hypothetical disasters make disasters more

\footnotetext{
${ }^{15}$ The relation between real past disaster experience and actual insurance take-up shows a similar pattern: a one percent increase in loss in the previous year increases insurance take-up by 0.36 percentage points; this result is significant at the $5 \%$ level. By contrast, a one percent increase in loss two years before increases insurance take-up by 0.19 percentage points; this result is not significant $(\mathrm{p}=0.319)$. Finally, a one percent increase in loss three years before reduces insurance take-up by 0.16 percentage points; again, this result is not significant $(\mathrm{p}=0.412)$.
} 
salient to farmers ${ }^{16}$. Lastly, the recency effect can be driven by people's failure to iterate (Camerer et al. (2004)), so that they think only the final rounds of the game lead to the overall game outcomes. To test the above two mechanisms, we look at the effect of the number of hypothetical disasters on post-game perceived probability of future disasters. If the recency effect is driven by a salience effect or failure of iteration, we should see a similar effect on the perceived probability of disaster. The results in Table 7, column (1) show that experiencing a disaster in the last round increases the perceived probability of disaster by 3.9 percentage points, which is significant at the $5 \%$ level. Experiencing an additional disaster in the last two rounds increases the perceived probability of disaster by 2.3 percentage points, again significant at the $5 \%$ level (Table 7 , column (2)). By contrast, disaster experience in the first seven rounds has no effect on participants' perceived probability of disaster (Table 7 column (3)). Together, these results support the explanation that the recency effect is due to a salience effect or the failure of iteration.

In our setting, the subjects face two lotteries: one without purchasing insurance, and the other with insurance purchase. The subjects choose between the two lotteries based on decision weights in favor of the salient payoff. The experience about hypothetical disasters, especially the recent disasters, can make the state with disaster more salient (more available) to the subjects. As a result, the local thinker evaluates the lottery by inflating the relative weights attached to the state with disaster. Hence, we observed that recent hypothetical disasters during the game increased the insurance take-up.

\footnotetext{
${ }^{16}$ According to Taylor and Thompson (1982), "Salience refers to the phenomenon that when one's attention is differentially directed to one portion of the environment rather than to others, the information contained in that portion will receive disproportionate weighting in subsequent judgments." Recent literature applies salience theory to explain consumer decisions (Koszegi and Szeidl (2013), Bordalo et al. (2013a)), choice under risk (Bordalo et al. (2013b)), and financial behavior (Alan et al. (2016)).
} 
Table 7. The Effect of the Number of Hypothetical Disasters on Perceived Probability of Future Disasters

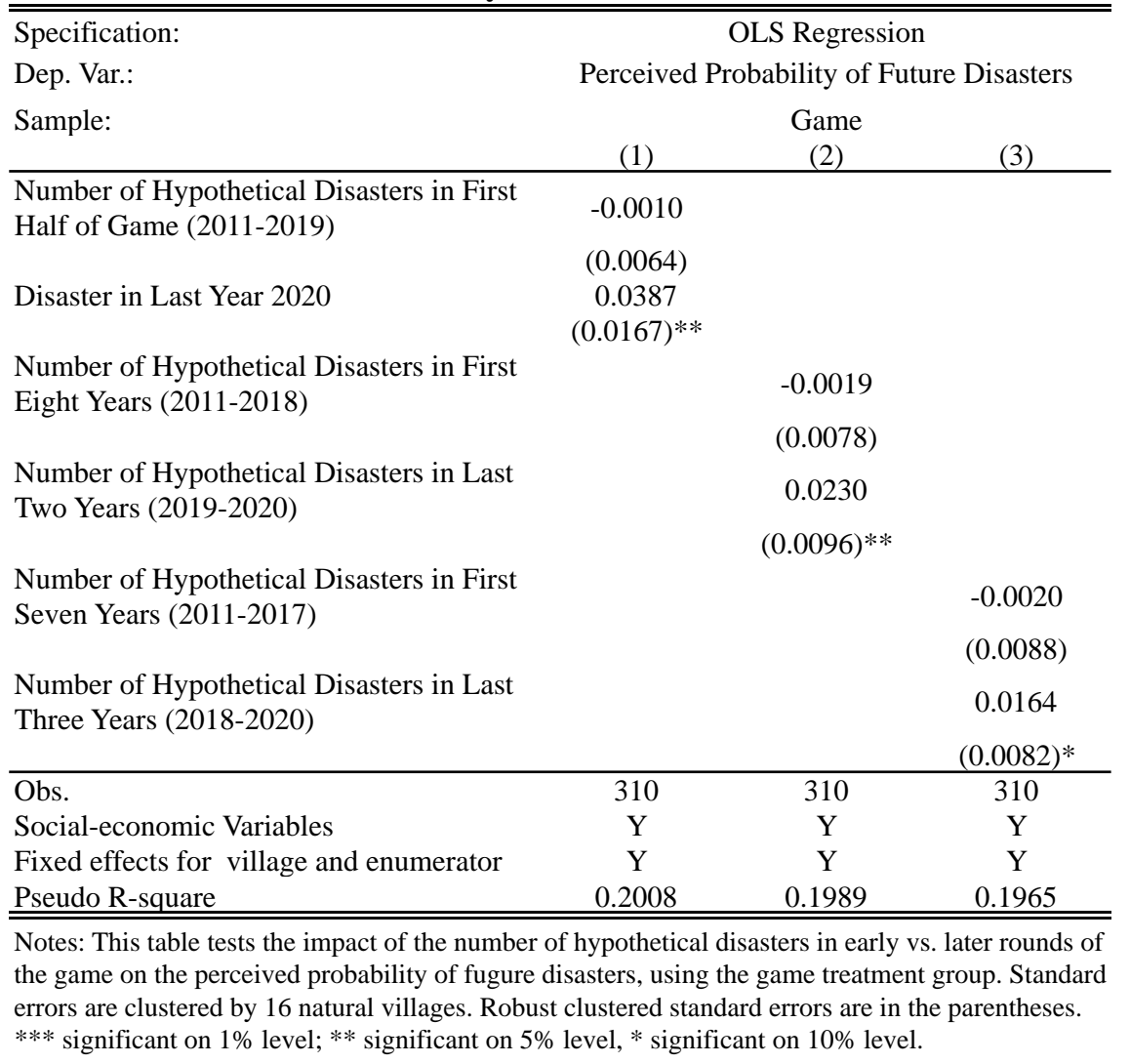

\subsection{The Impact of Probability Treatment on Insurance Take-up}

The second main intervention we implement to improve insurance take-up is the probability treatment, in which the true probability of natural disasters is explicitly revealed to farmers. According to Figure 5, farmers in the probability treatment group have a higher average take-up than those in the no-probability group.

To test whether this effect is statistically significant, we run the following regression:

$$
\text { buy }_{i j}=\alpha_{j}+\alpha_{k}+\delta_{p} \text { Probability }_{i j}+\phi X_{i j}+\epsilon_{i j}
$$


Figure 5. Treatment Effects by the Probability Treatment

Take-up

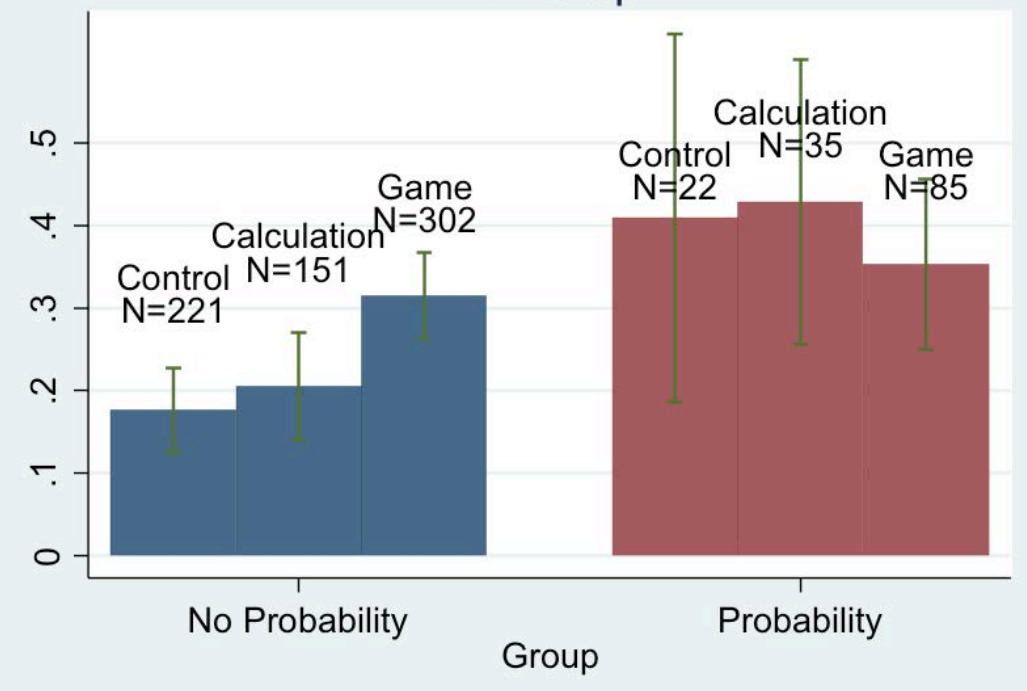

Notes: This figure shows the treatment effect by the probability treatment. Without the probability treatment, the game treatment is more effective than the calculation treatment. With the probability treatment, neither the game treatment nor the calculation treatment is as effective.

where Probability $y_{i j}$ is an indicator that takes a value of one if household $i$ in natural village $j$ is in the probability treatment group and zero otherwise.

We present the results of this regression in Table 8. According to the results in columns (1) and (2), the probability treatment increases insurance take-up significantly: farmers who receive the probability treatment are almost 30 percentage points more likely to buy the insurance. Thus, providing knowledge about the probability of disasters can help farmers understand the value of the insurance product, and as a consequence improves insurance take-up rates. 
Table 8. The Effect of Probabiity Treatment on Insurance Take-up

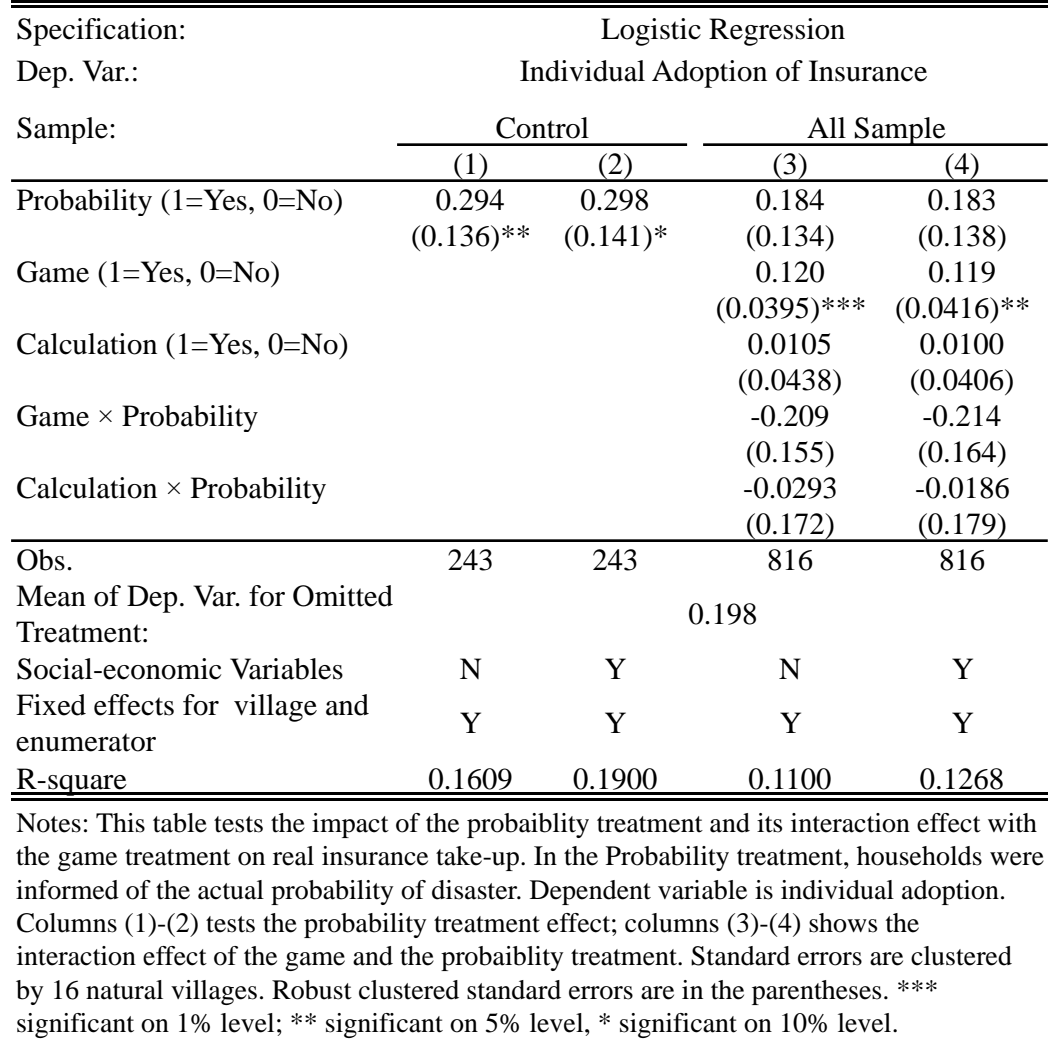

\subsection{The Interaction Effect of the Game/Calculation and the Prob-} ability Treatment

The game/calculation treatment effects can be different depending on whether farmers were provided with information about the actual probability of disasters. To test the interaction effect between the game and the probability treatment, we run the following estimation:

$$
\begin{gathered}
\text { buy }_{i j}=\alpha_{j}+\alpha_{k}+\beta_{g} T g_{i j}+\gamma_{c r} T c_{i j}+\delta_{p} \text { Probability }_{i j}+\eta_{1} T g_{i j} * \text { Probability }_{i j} \\
+\eta_{2} T c_{i j} * \text { Probability }_{i j}+\phi X_{i j}+\epsilon_{i j}
\end{gathered}
$$


The results of this estimation are shown in column (3) of Table 8. Surprisingly, we find that the game and the probability treatment cancel each other out. In other words, both the game and the calculation treatment effects are much smaller when farmers are told about the true probability of disasters, although the interaction is not statistically significant.

One explanation for this finding is that our participants may dismiss the value of the insurance game if it provides disaster results that contradict the real probability of disaster. To test this, we estimate the heterogeneity of the probability treatment effect depending on the number of hypothetical disasters experienced during the game. We find that, conditional on zero hypothetical disasters during the game, the probability treatment effect is 0.015 and insignificant. However, the effect becomes $-0.023,-0.058$ and -0.114 respectively, conditional on one, two or three hypothetical disasters during the game. These results suggest that farmers may value the game less if it does not coincide with the real disaster

probability, and thus the game treatment disappears when the true probability of disaster is provided. However, we should note again that our small probability subsample precludes us from estimating these effects precisely.

\subsection{Discussion}

While our analyses have shown that hypothetical disaster experience can increase insurance take-up rates, we acknowledge that weather insurance take-up rates in rural China remain quite low. Even with the high government subsidy, the overall take-up rate is only 30\%, while our calibration results in Appendix B suggest that a $70 \%$ government subsidy should lead to a take-up rate of $60 \%$. In this section, we use our data to examine why the overall take-up rate is low. Specifically, we consider the following explanations: lack of trust in the government or the insurance company, perceptions of high transaction costs, and the 
availability of non-insurance-based government relief.

To test the impact of trust on insurance take-up, we use two methods. First, we test for the correlation between weather insurance take-up and experience with purchasing other insurance products. Our results in columns (1)-(3) in Table A5 show that those who have purchased life or asset insurance are less likely to buy rice insurance. The reason could be that these households have had a negative experience with the purchase of insurance and thus have less trust in insurance companies ${ }^{17}$. Second, we construct several measures of trust, including the self-reported level of trust in the insurance company as well as the household's payout experience with other insurance products, and relate these measures to insurance adoption decisions. We report the results in columns (4)-(6) in Table A5. The results in column (4) show that the self-reported level of trust in insurance companies is positively correlated with insurance take-up. Column (5) shows the results when we measure trust by a dummy variable equal to one if a household has received a payout from another insurance contract and zero otherwise. These results show that those who have received payouts before are more likely to buy rice insurance. Finally, the results in column (6) show no effect of observing other villagers receiving a payout from other insurance products on a given farmer's insurance take-up. Together, these results suggest that a lack of trust on the insurance company is another important factor influencing insurance take-up. However, this should not affect the results of our experiment because the trust indicators are balanced between the treatment and control groups as shown in Table 1, Panel A.

We also consider the possibility that the low insurance take-up is due to the anticipation of high transaction costs or long delays in receiving payouts. However, we dismiss these as possible explanations in our setting as our insurance contract states that the payout

\footnotetext{
${ }^{17}$ These two types of insurance were offered to all households in the early 2000s; in some cases, the insurance company did not repay after losses were reported.
} 
will be issued within ten days after a loss report. Moreover, starting in 2004, the Chinese government began depositing annual rice production subsidies in each farmer's bank account; any insurance payout would thus be conveniently made through the same bank account.

Lastly, farmers may not feel they need insurance since the government provides relief if major natural disasters occur. However, according to our conversations with local farmers, these transfers are usually far from sufficient to help them resume production - in most cases the government only distribute small amount of money (less than 50 RMB per household) or some vegetables. Consequently, we conclude that the availability of government relief does not explain the low insurance take-up rate.

In sum, the above results suggest that in our context, the lack of trust on the insurance company can be another potential factor driving the low take-up rate. As a result, making sure that payouts are distributed fairly and on time is important in improving long-term take-up rates.

\section{Conclusion}

In this paper, we offer new evidence on the impact of disaster experience and knowledge on weather insurance take-up rates. First, substituting real experience with hypothetical experience in a game setting, we find that playing an insurance game increases the real insurance take-up rate by 9.1 percentage points, a $46 \%$ increase relative to the baseline takeup rate of $20 \%$. After investigating possible mechanisms that could be driving this effect, we find that exposure to hypothetical disasters is the main explanation for the observed effect. In a second intervention, we examine the impact of improving knowledge about the expected benefits of the insurance product by explicitly revealing the true probability of disasters in 
the past ten years. We find that this treatment also has a strong effect on real insurance take-up rates. Interestingly, participating in the game coupled with receiving information about the true probability of disasters reduces the game effect, albeit not significantly.

Our results suggest that, first, the large impact of the game treatment on real insurance take-up and the insignificant effect of the calculation treatment suggest that, giving households a rule of thumb to follow through simulated experiences could be more effective in improving their decision-making compared with offering theoretical training. Similar interventions can be used on a broader level to influence the adoption of other financial products that involve uncertainty and require some time to experience the gain or loss. Second, our results show that informing farmers about the real probability of disasters can help them estimate the product value and thus lead them to make better-informed purchase decisions. Many other financial decisions also involve complexities that individuals have difficulty understanding based on their own information. In many cases, financial education is provided to help people make decisions. Our findings suggest that providing information on the true expected values of financial assets could be important in improving the effectiveness of financial education. 


\section{References}

Aker, Jenny C. and Isaac M. Mbiti, "Mobile Phones and Economic Development in Africa," Journal of Economic Perspectives, 2010, 24 (3), 207-32.

Alan, Sule, Mehmet Cemalcilar, Dean Karlan, and Jonathan Zinman, "Unshrouding Effects on Demand for a Costly Add-on: Evidence from Bank Overdrafts in Turkey," Working Paper, 2016.

Ashraf, Nava, Dean Karlan, and Wesley Yin, "Tying Odysseus to the Mast: Evidence from a Commitment Savings Product in the Philippines," The Quarterly Journal of Economics, May 2006, 121 (2), 635-672.

Benz, Matthias and Stephan Meier, "Do people behave in experiments as in the field? evidence from donations," Experimental Economics, 2008, 11 (3), 268-281.

Bordalo, Pedro, Nicola Gennaioli, and Andrei Shleifer, "Salience and Consumer Choice," Journal of Political Economy, 2013a, 121, 803-843.

_, _, and _, "Saliance and Asset Prices," American Economic Review Papers and Proceedings, 2013b, 103 (3), 623-628.

Cai, Jing, "The Impact of Insurance Provision on Household Production and Financial Decisions," American Economic Journal: Economic Policy, 2015, Forthcoming.

_, Alain de Janvry, and Elisabeth Sadoulet, "Social Networks and the Decision to Insure," Americal Economic Journal: Applied Economics, 2015, 7 (2), 81-108.

Camerer, Colin F., Teck-Hua Ho, and Juin-Kuan Chong, "A Cognitive Hierarchy Model of Games," Quarterly Journal of Economics, 2004, 119 (3), 861-898. 
Cole, Shawn, Petia Topalova, , Xavier Gene, Jeremy Tobacman, Robert Townsend, and James Vickery, "Barriers to Household Risk Management: Evidence from India," Americal Economic Journal: Applied Economics, 2013, 5 (1), 104-35.

_, Xavier Giné, and James Vickery, "How Does Risk Management In- fluence Production Decisions? Evidence from a Field Experiment," HBS Working Paper 13-080, 2013.

Drexler, Alejandro, Greg Fischer, and Antoinette Schoar, "Keeping It Simple: Financial Literacy and Rules of Thumb," American Economic Journal: Applied Economics, 2014, $6(2), 1-31$.

Einav, Liran, Amy Finkelstein, and Jonathan Levin, "Beyond Testing: Empirical Models of Insurance Markets," Annual Review of Economics, 09 2010, 2 (1), 311-336.

Erev, Ido and Ernan Haruvy, "Learning and the Economics of Small Decisions," The Handbook of Experimental Economics, 2013, 2.

Fehr, Ernst and Lorenz Goette, "Do Workers Work More if Wages Are High? Evidence from a Randomized Field Experiment," American Economic Review, March 2007, 97 (1), $298-317$.

Fredrickson, B.L. and D. Kahneman, "Duration neglect in retrospective evaluations of affective episodes," Journal of Personality and Social Psychology, 1993, 65, 45-55.

Gallagher, Justin, "Learning about an Infrequent Event: Evidence from Flood Insurance Take-up in the US," Americal Economic Journal: Applied Economics, 2014, 6 (3), 206-33. 
Gaurav, Sarthak, Shawn Cole, and Jeremy Tobacman, "The Randomized Evaluation of Financial Literacy on Rainfall Insurance Take-up in Gujarat," ILO Microinsurance Innovation Facility Research Paper, 2011, (1).

Gazzale, Robert S., Julian Jamison, Alexander Karlan, and Dean S. Karlan, "Ambiguous Solicitation: Ambiguous Prescription," Economic Inquiry, 2011, 51 (1), 10021011.

Giné, Xavier, Robert Townsend, and James Vickery, "Patterns of Rainfall Insurance Participation in Rural India," World Bank Economic Review, October 2008, 22 (3), 539566.

Haisley, Emily and George Loewenstein, "It's Not What You Get but When You Get It: The Effect of Gift Sequence on Deposit Balances and Customer Sentiment in a Commercial Bank," Journal of Marketing Research, 2011, 48 (1), 103-115.

Haselhuhn, Michael P., Devin G. Pope, and Maurice E. Schweitzer, "Size Matters (and so Does Experience): How Personal Experience with a Fine Influences Behavior," Working Paper, 2009.

Healy, Andrew and Gabriel S. Lenz, "Substituting the End for the Whole: Why Voters Respond Primarily to the Election-Year Economy," American Journal of Political Science, 2014, $58(1), 31-47$.

Hong, Harrison, Jeffrey D. Kubik, and Jeremy C. Stein, "Social Interaction and Stock-Market Participation," Journal of Finance, 02 2004, 59 (1), 137-163.

Jack, Billy and Tavneet Suri, "RIsk Sharing and Transactions Costs: Evidence from Kenya's Mobile Money Revolution," American Economic Review, 2014, 104 (1), 183-223. 
Karlan, Dean, Robert Osei, Isaac Osei-Akoto, and Christopher Udry, "Agricultural Decisions after Relaxing Credit and Risk Constraints," The Quarterly Journal of Economics, 2014, 129 (2), 597-652.

Karlan, Dean S., Julian Jamison, and Jonathan Zinman, "Financial Education and Access to Savings Accounts: Complements or Substitutes? Evidence from Ugandan Youth Clubs," May 2014.

Kaustia, Markku and Samuli Knüpfer, "Do Investors Overweight Personal Experience? Evidence from IPO Subscriptions," Journal of Finance, 2008, 63 (6).

Koszegi, Botond and Adam Szeidl, "A Model of Focusing in Economic Choice," Quarterly Journal of Economics, 2013, 128, 53-107.

Malmendier, Ulrike and Stefan Nagel, "Depression Babies: Do Macroeconomic Experiences Affect Risk Taking?," The Quarterly Journal of Economics, 2011, 126 (1), 373-416.

Schreiber, C. A. and D. Kahneman, "Determinants of the remembered utility of aversive sounds," Journal of Experimental Psychology: General, 2000, 129, 27-42.

Taylor, S. E. and S. C. Thompson, "Stalking the Elusive Vividness Effect," Psychological Review, 1982, 89, 155-181. 


\section{Appendices}

A Supplementary Figures and Tables 


\section{Table A1. Description of the Calculation Treatment}

\begin{tabular}{ccc}
\hline \hline $\begin{array}{c}\text { Number of } \\
\text { disasters in } \\
10 \text { years }\end{array}$ & $\begin{array}{c}\text { Total ten years' income if you purchased } \\
\text { insurance every year }\end{array}$ & $\begin{array}{c}\text { Total ten years' income if you did not } \\
\text { purchase insurance in any year }\end{array}$ \\
\hline 0 & $99640=10000-3.6 * 10 \mathrm{mu}^{*} 10 \mathrm{year}$ & $100000=1000 * 10 \mathrm{mu}^{*} 10 \mathrm{year}$ \\
1 & $96440=96000-360+200 * 40 \% * 10 \mathrm{mu}^{*} 1 \mathrm{year}$ & $96000=100000-400 * 10 \mathrm{mu} * 1 \mathrm{year}$ \\
2 & $93240=92000-360+200 * 40 \% * 10 \mathrm{mu}^{*} 2 \mathrm{year}$ & $92000=100000-400 * 10 \mathrm{mu}$ *2year \\
3 & $90040=88000-360+200 * 40 \% * 10 \mathrm{mu} * 3 \mathrm{year}$ & $88000=100000-400 * 10 \mathrm{mu} * 3 \mathrm{year}$ \\
\hline \hline
\end{tabular}

Notes: This table describes the main information included in the calculation treatment. Based on this table, the enumerators demonstrate how to calculate the expected payoff of buying/not buying insurance if zero, one, two or three disasters were to occur at any time in the following ten years.

Table A2. Description of the Game Treatment

\begin{tabular}{cccc}
\hline \hline Up-take & Disaster & Income (RMB) & Note \\
\hline NO & NO & $10000=1000 * 10 \mathrm{mu}$ & $\begin{array}{c}\text { Assume when there's no disaster, the gross income per mu } \\
\text { is 1000 RMB }\end{array}$ \\
NO & YES & $6000=600 * 10$ & $\begin{array}{c}\text { Assume if a } 40 \% \text { disaster happened, the gross income per } \\
\text { mu is 600 RMB }\end{array}$ \\
YES & NO & $9964=1000 * 10-3.6 * 10$ & $\begin{array}{c}\text { Assume when there's no disaster, the gross income per mu } \\
\text { is } 1000 \mathrm{RMB} \text {, and the premium is 36 RMB in total. } \\
\text { Assume if a } 40 \% \text { disaster happened, the gross income per } \\
\text { mu is 600 RMB, and the premium is 36 RMB in total. The } \\
\text { payout per mu is 200*40\%=80 RMB. }\end{array}$ \\
\hline \hline
\end{tabular}

\begin{tabular}{ccc}
\hline \hline Year & $\begin{array}{c}\text { Do you } \\
\text { buy the } \\
\text { insurance? }\end{array}$ & $\begin{array}{c}\text { Why do you buy/not buy } \\
\text { the insurance }\end{array}$ \\
\hline 2011 & & Have you experienced disaster in this year? \\
2012 & $\begin{array}{c}\text { Income in this } \\
\text { year }\end{array}$ \\
$\ldots$ & \\
2020 & \\
\hline \hline
\end{tabular}

Notes: This table presnts the main information conveyed to the game group. The household head is first asked whether he or she would like to purchase insurance in the year 2011. The participant then plays a lottery which reveals whether a disaster occurs in that year. In the lottery, the participant draws a card from a stack of ten cards. The enumerators first show ten cards to the participants and thus they can see how many cards signify disasters. After the lottery result is revealed, the enumerator and the participant calculate the income from that year based on the assumed expected income per acre and any insurance payment according to this table. The game is then played for another nine rounds, representing years 2012 to year 2020, respectively. In each round, the participant draws from a deck of ten cards to determine whether a disaster occurs in that year. 
Table A3. The Heterogeneity Effect of Game Treatment on Insurance Knowledge

\begin{tabular}{|c|c|c|c|c|}
\hline \multirow{4}{*}{$\begin{array}{l}\text { Specification: } \\
\text { Sample } \\
\text { Dep. Var.: }\end{array}$} & \multicolumn{4}{|c|}{ OLS Regression } \\
\hline & \multicolumn{4}{|c|}{ All Sample } \\
\hline & \multicolumn{2}{|c|}{$\begin{array}{c}\text { Whether subjects answer the } \\
\text { insurance benefit questions } \\
\text { correctly }\end{array}$} & \multicolumn{2}{|c|}{$\begin{array}{l}\text { Whether subjects answer the } \\
\text { insurance benefit questions }\end{array}$} \\
\hline & Question 1 & Question 2 & Question 1 & Question 2 \\
\hline & $(1)$ & $(2)$ & (3) & (4) \\
\hline \multirow[t]{2}{*}{ Game $(1=$ Yes, $0=$ No $)$} & 0.0355 & 0.0695 & 0.0126 & 0.0105 \\
\hline & $(0.0515)$ & $(0.0599)$ & $(0.0158)$ & $(0.0248)$ \\
\hline \multirow[t]{2}{*}{ Game $\times$ Education } & -0.0199 & -0.0401 & & \\
\hline & $(0.0352)$ & $(0.0360)$ & & \\
\hline$\overline{\text { Obs. }}$ & 658 & 657 & 658 & 657 \\
\hline Omitted Treatment & \multicolumn{4}{|c|}{ Control } \\
\hline $\begin{array}{l}\text { Mean of Dep. Var. for } \\
\text { Omitted Treatment: }\end{array}$ & 0.416 & 0.265 & 0.432 & 0.416 \\
\hline Social-economic Variables & $\mathrm{Y}$ & Y & $\mathrm{Y}$ & $\mathrm{Y}$ \\
\hline $\begin{array}{l}\text { Fixed effects for village and } \\
\text { enumerator }\end{array}$ & Y & Y & Y & $\mathrm{Y}$ \\
\hline R-square & 0.7695 & 0.6896 & 0.8068 & 0.6579 \\
\hline
\end{tabular}

Notes: Insurance Benefit Question 1 is "Suppose your gross income is $1000 \mathrm{RMB}$ per mu, the loss from disaster is $400 \mathrm{RMB}$, insurance premium is $3.6 \mathrm{RMB}$, you get $80 \mathrm{RMB}$ from insurance company if there is a disaster and you buy the insurance. What is your income per mu if there is a disaster but you did not buy insurance? " Insurance Benefit Question 2 is "What is your income per mu if there is a disaster and you bought the insurance?" Standard errors are clustered by 16 natural villages. Robust clustered standard errors are in the bracket;*** significant on $1 \%$ level, ** significant on $5 \%$ level, * significant on $10 \%$ level. 
Table A4. The Effect of Hypothetical Disasters Experienced in Earlier vs. Later Rounds of the Game on Actual Insurance Take-up

\begin{tabular}{|c|c|c|c|c|c|c|c|c|c|}
\hline \multirow{4}{*}{$\begin{array}{l}\text { Specification: } \\
\text { Dep. Var.: } \\
\text { Sample: }\end{array}$} & \multicolumn{9}{|c|}{ Logistic Regression } \\
\hline & \multicolumn{9}{|c|}{ Individual Adoption of Insurance } \\
\hline & & & & $\mathrm{Ga}$ & me & & & & \\
\hline & $(1)$ & $(2)$ & (3) & (4) & $(5)$ & (6) & $(7)$ & $(8)$ & $(9)$ \\
\hline Hypothetical Disaster in 2011 & $\begin{array}{c}-0.134 \\
(0.079)^{*}\end{array}$ & & & & & & & & \\
\hline $\begin{array}{l}\text { Number of Hypothetical Disasters } \\
\text { in Last Nine Years (2012-2020) }\end{array}$ & $\begin{array}{c}0.032 \\
(0.012)^{* * *}\end{array}$ & & & & & & & & \\
\hline $\begin{array}{l}\text { Number of Hypothetical Disasters } \\
\text { in First Two Years (2011-2012) }\end{array}$ & & $\begin{array}{c}-0.102 \\
(0.036)^{* * *}\end{array}$ & & & & & & & \\
\hline $\begin{array}{l}\text { Number of Hypothetical Disasters } \\
\text { in Last Eight Years (2013-2020) }\end{array}$ & & $\begin{array}{c}0.077 \\
(0.026)^{* * *}\end{array}$ & & & & & & & \\
\hline $\begin{array}{l}\text { Number of Hypothetical Disasters } \\
\text { in First Three Years (2011-2013) }\end{array}$ & & & $\begin{array}{c}-0.077 \\
(0.034)^{* *}\end{array}$ & & & & & & \\
\hline $\begin{array}{l}\text { Number of Hypothetical Disasters } \\
\text { in Last Seven Years (2014-2020) }\end{array}$ & & & $\begin{array}{c}0.080 \\
(0.027)^{* * *}\end{array}$ & & & & & & \\
\hline $\begin{array}{l}\text { Number of Hypothetical Disasters } \\
\text { in First Four Years (2011-2014) }\end{array}$ & & & & $\begin{array}{c}-0.053 \\
(0.028)^{*}\end{array}$ & & & & & \\
\hline $\begin{array}{l}\text { Number of Hypothetical Disasters } \\
\text { in Last Six Years (2015-2020) }\end{array}$ & & & & $\begin{array}{c}0.084 \\
(0.026)^{* * *}\end{array}$ & & & & & \\
\hline $\begin{array}{l}\text { Number of Hypothetical Disasters } \\
\text { in First Five Years (2011-2015) }\end{array}$ & & & & & $\begin{array}{c}0.020 \\
(0.033)\end{array}$ & & & & \\
\hline $\begin{array}{l}\text { Number of Hypothetical Disasters } \\
\text { in Last Five Years (2016-2020) }\end{array}$ & & & & & $\begin{array}{c}0.067 \\
(0.040)^{*}\end{array}$ & & & & \\
\hline $\begin{array}{l}\text { Number of Hypothetical Disasters } \\
\text { in First Six Years (2011-2016) }\end{array}$ & & & & & & $\begin{array}{c}0.013 \\
(0.028)\end{array}$ & & & \\
\hline $\begin{array}{l}\text { Number of Hypothetical Disasters } \\
\text { in Last Four Years (2017-2020) }\end{array}$ & & & & & & $\begin{array}{c}0.039 \\
(0.044)\end{array}$ & & & \\
\hline $\begin{array}{l}\text { Number of Hypothetical Disasters } \\
\text { in First Seven Years (2011-2017) }\end{array}$ & & & & & & & $\begin{array}{c}0.005 \\
(0.026)\end{array}$ & & \\
\hline $\begin{array}{l}\text { Number of Hypothetical Disasters } \\
\text { in Last Three Years (2018-2020) }\end{array}$ & & & & & & & $\begin{array}{c}0.068 \\
(0.043)\end{array}$ & & \\
\hline $\begin{array}{l}\text { Number of Hypothetical Disasters } \\
\text { in First Eight Years (2011-2018) }\end{array}$ & & & & & & & & $\begin{array}{c}0.025 \\
(0.027)\end{array}$ & \\
\hline $\begin{array}{l}\text { Number of Hypothetical Disasters } \\
\text { in Last Two Year (2019-2020) }\end{array}$ & & & & & & & & $\begin{array}{c}0.057 \\
(0.057)\end{array}$ & \\
\hline $\begin{array}{l}\text { Number of Hypothetical Disasters } \\
\text { in First Nine Years (2011-2019) }\end{array}$ & & & & & & & & & $\begin{array}{c}0.004 \\
(0.014)\end{array}$ \\
\hline $\begin{array}{l}\text { Number of Hypothetical Disasters } \\
\text { in Last Year (2020) }\end{array}$ & & & & & & & & & $\begin{array}{l}0.1108 \\
(0.070) \\
\end{array}$ \\
\hline Obs. & 375 & 375 & 375 & 375 & 375 & 375 & 375 & 375 & 375 \\
\hline Omitted Treatment & & & & Control & & & & & \\
\hline $\begin{array}{l}\text { Mean of Dep. Var. for Omitted } \\
\text { Treatment: }\end{array}$ & & & & 0.198 & & & & & \\
\hline Social-economic Variables & $\mathrm{Y}$ & $\mathrm{Y}$ & $\mathrm{Y}$ & $\mathrm{Y}$ & $\mathrm{Y}$ & $\mathrm{Y}$ & $\mathrm{Y}$ & $\mathrm{Y}$ & $\mathrm{Y}$ \\
\hline $\begin{array}{l}\text { Fixed effects for village and } \\
\text { enumerator }\end{array}$ & Y & Y & Y & Y & Y & Y & Y & Y & Y \\
\hline Log Likelihood & -221 & -218 & -218 & -219 & -221 & -223 & -222 & -222 & -222 \\
\hline Pseudo R-square & 0.0628 & 0.0772 & 0.0763 & 0.0733 & 0.0631 & 0.0563 & 0.0601 & 0.0586 & 0.0586 \\
\hline
\end{tabular}

Notes: In this table, we regress insurance take-up on the number of hypothetical disasters in the first (10-\$n\$) rounds and that in the last $\mathrm{n}$ rounds. Dependent variable is individual adoption. Standard errors are clustered by 16 natural villages. Robust clustered standard errors are in the parentheses. *** significant at $1 \%$ level; ** significant at $5 \%$ level; * significant at $10 \%$ level. 
Table A5. The Impact of Trust on Weather Insurance Take-up

Specification:

Dep. Var.:

Sample:
Linear Regression

Individual adoption of insurance

All Sample

\begin{tabular}{|c|c|c|c|c|c|c|}
\hline & (1) & $(2)$ & (3) & $(4)$ & $(5)$ & (6) \\
\hline \multirow[t]{2}{*}{ Game } & 0.094 & 0.094 & 0.093 & 0.118 & 0.114 & 0.111 \\
\hline & $(0.041)^{* * *}$ & $(0.029) * * *$ & $(0.030)^{* * *}$ & $(0.035)^{* * *}$ & $(0.037)^{* * *}$ & $(0.037)^{* * *}$ \\
\hline \multirow[t]{2}{*}{ Health Insurance } & 0.103 & & & & & \\
\hline & $(0.072)$ & & & & & \\
\hline \multirow[t]{2}{*}{ Life Insurance } & & -0.135 & & & & \\
\hline & & $(0.043)^{* * *}$ & & & & \\
\hline \multirow[t]{2}{*}{ Asset Insurance } & & & -0.086 & & & \\
\hline & & & $(0.041)^{*}$ & & & \\
\hline \multirow[t]{2}{*}{ Self-Report Positive Trust Indicator } & & & & 0.472 & & \\
\hline & & & & $(0.073)^{* * *}$ & & \\
\hline \multirow[t]{2}{*}{ Self-Report Negative Trust Indicator } & & & & -0.425 & & \\
\hline & & & & $(0.076)^{* * *}$ & & \\
\hline \multirow[t]{2}{*}{ Self-Claim Positive Trust Indicator } & & & & & 0.118 & \\
\hline & & & & & $(0.065)^{*}$ & \\
\hline \multirow[t]{2}{*}{ Self-Claim Negative Trust Indicator } & & & & & 0.024 & \\
\hline & & & & & $(0.041)$ & \\
\hline \multirow[t]{2}{*}{ Other-Claim Positive Trust Indicator } & & & & & & -0.039 \\
\hline & & & & & & $(0.044)$ \\
\hline \multirow[t]{2}{*}{ Other-Claim Negative Trust Indicator } & & & & & & 0.026 \\
\hline & & & & & & $(0.050)$ \\
\hline \multirow[t]{2}{*}{ \%Loss Last Year (self report) } & 0.245 & 0.236 & 0.247 & & & \\
\hline & $(0.097)^{* *}$ & $(0.095)^{* *}$ & $(0.097)^{* *}$ & & & \\
\hline \multirow[t]{2}{*}{ Age } & 0.005 & 0.006 & 0.007 & -0.003 & 0.003 & -0.005 \\
\hline & $(0.010)$ & $(0.010)$ & $(0.010)$ & $(0.011)$ & $(0.011)$ & $(0.011)$ \\
\hline \multirow[t]{2}{*}{ Education } & 0.052 & 0.054 & 0.053 & 0.025 & 0.052 & 0.053 \\
\hline & $(0.019)^{* *}$ & $(0.018) * * *$ & $(0.018)^{* * * *}$ & $(0.019)$ & $(0.019)^{* *}$ & $(0.018)^{* *}$ \\
\hline \multirow[t]{2}{*}{ Household Size } & -0.024 & -0.022 & -0.023 & -0.041 & -0.024 & -0.027 \\
\hline & $(0.006)^{* * * *}$ & $(0.007) * * *$ & $(0.007) * * *$ & $(0.010)^{* * * *}$ & $(0.006)^{* * * *}$ & $(0.008)^{* * *}$ \\
\hline \multirow[t]{2}{*}{ Land of Rice Production } & 0.005 & -0.004 & -0.004 & 0.033 & 0.004 & 0.009 \\
\hline & $(0.013)$ & $(0.013)$ & $(0.013)$ & $(0.015)^{*}$ & $(0.014)$ & $(0.013)$ \\
\hline Obs. & 816 & 816 & 816 & 816 & 816 & 816 \\
\hline $\begin{array}{l}\text { Fixed Effects for Village and } \\
\text { Enumerator }\end{array}$ & $\mathrm{N}$ & $\mathrm{N}$ & $\mathrm{N}$ & $\mathrm{N}$ & $\mathrm{N}$ & $\mathrm{N}$ \\
\hline $\mathrm{R}$-square & 0.0489 & 0.0503 & 0.0501 & 0.2341 & 0.0489 & 0.0421 \\
\hline
\end{tabular}

Notes: This table explores the impact of trust on insurance take-up. Columns (1)-(3) present the correlation between weather insurance take-up and other insurance. In columns (4)-(6), we construct several measures of trust and relating them to insurance adoption decisions. In column (4), the trust indicator is defined as the self-reported level of trust on the insurance company; in column (5), trust is defined as a dummy variable which equals one if a household has received a payout from another insurance contract and zero otherwise; in column (6), trust is measured by whether a household observed other villagers receiving payouts from other insurance policies. Dependent variable is individual adoption; Robust clustered (to natural village level) standard errors are in the bracket. *** significant on $1 \%$ level, ** significant on $5 \%$ level, * significant on $10 \%$ level. 


\section{B Insurance Demand Models}

The evidence discussed in our paper implies that hypothetical experience influences actual insurance decisions. Does our intervention improve household welfare? In this section, we present a simple model to calibrate insurance take-up using the parameter elicited from our surveys. We show that a standard constant absolute risk aversion (CARA) preference is unlikely to explain the data.

We consider the following simple model with CARA preferences commonly used in the insurance literature (Einav et al. (2010)).

$$
u(x)=-\frac{\exp (-\alpha x)}{\alpha}
$$

With CARA preferences, a consumer's wealth does not affect his insurance choices. Therefore, an insurance take-up decision should be determined by the joint distribution of risk attitudes and the perceived probability of future disasters.

We first let $U(a)$ denote the household utility as a function of the insurance decision. $a=1$ if the household buys the insurance and $a=0$ if the household does not buy the insurance. We also let $(b, \tau)$ denote the insurance contract in which $b$ is the repayment of insurance if there is a disaster and $\tau$ is the premium. Finally, we let $x$ indicate the gross income from rice production, $p$ the perceived probability of future disasters and $l$ the loss in yield. The expected utility of not buying insurance is thus represented by:

$$
U(a=0)=(1-p) u(x)+p u(x-l)
$$

If a household buys insurance, it should earn its normal income and pay the premium 
when there is no disaster. It will then receive a payment from the insurance company when there is a disaster. The utility of buying insurance is thus represented by:

$$
U(a=1)=(1-p) u(x-\tau)+p u(x-\tau-l+b)
$$

The condition for the household to buy the insurance is:

$$
U(a=1) \geq U(a=0)
$$

It is straightforward to show that those households that are more risk averse and whose perceived probabilities of future disasters are larger are more likely to buy insurance.

To test whether a standard CARA preference could explain our data, we can use the parameter as measured, calibrate individual decisions and compare the calibrated decisions with actual decisions. In this test, we assume that there is no measurement error for either risk aversion $(\alpha)$ or perceived probability of future disasters $(p)$. Although we do not observe parameter $\alpha$, we can make use of their choices in Table 1 to estimate the intervals of their $\alpha$ in the utility function. The intervals of $\alpha$ under CARA are presented in Table B1. If a household takes two riskless options, then $\alpha$ should be greater than zero and less than 0.0041 under a CARA preference ${ }^{18}$.

We find that the mean for our simulated insurance take-up is $58.6 \%$ at post-subsidy price

\footnotetext{
${ }^{18}$ Simulation of Insurance Take-up under Standard Model:
}

1. Take a uniform draw of $\alpha$ from the interval according to each household's choices of riskless options

2. Take two extreme type I error term and difference them to get logistic error term

3. Use the draw of $\alpha$, self-reported $p$ and the error term to calculate the insurance decision of each household and the percentage of take-up in the simulated sample

4. Repeat 1 to 3 for 100 times and calculate the mean and standard deviation of take-up. 
(3.6 RMB) and $47.3 \%$ at full price (12 RMB). This contradicts our actual data which shows a take-up mean of $20 \%$ in the control group and about $30 \%$ in the treatment group. This difference suggests that standard CARA preferences are unlikely to explain our data.

A second way to test whether our results reflect CARA preferences is to ignore $\alpha$ and $p$ as elicited. In this case, suppose that we had not elicited measures for risk aversion and perceived probability of future disasters. We would then estimate $\alpha$ and $p$ in the logit formula through MLE:

$$
P(a=1)=\frac{\exp (U(a=0))}{\exp (U(a=1))+\exp (U(a=0))}
$$

However, in doing so, we find that the model is not identifiable. The log-likelihood function reaches a flat region and the combination of $\alpha$ and $p$ falls into the following two categories: (1) negative $\alpha$ (risk seeking) and $p$ greater than 17\% (2) positive $\alpha$ (risk averse) and $p$ less than $5 \%$. This finding contradicts our data that average risk attitude implies risk aversion and that the average perceived probability of future disasters is around $20 \%$.

In sum, both the calibrated decisions and estimated parameters methods provide results that contradict our data under standard CARA preferences. These results suggest that standard CARA preferences are unlikely to explain our observed increased insurance takeup and perceived probability of future disasters together. 
Table B1. Range of the Risk Aversion Parameter

\begin{tabular}{ccc}
\hline \hline $\begin{array}{c}\text { Number of Riskless } \\
\text { Options Taken }\end{array}$ & $\begin{array}{c}\text { Range } \alpha \text { of for CARA } \\
\mathrm{u}(\mathrm{x})=-\exp (-\alpha \mathrm{x}) / \alpha\end{array}$ & $\begin{array}{c}\text { Range } \alpha \text { of for CRRA } \\
\mathrm{u}(\mathrm{x})=\mathrm{x}^{1-\alpha} /(1-\alpha)\end{array}$ \\
\hline 0 & $\alpha<-0.0121$ & $\alpha<-1.4$ \\
1 & $-0.0121<\alpha<-0.0041$ & $-1.4<\alpha<-0.35$ \\
2 & $-0.0041<\alpha<0$ & $-0.35<\alpha<0$ \\
3 & $0<\alpha<0.0041$ & $0<\alpha<0.25$ \\
4 & $0.0041<\alpha<0.0121$ & $0.25<\alpha<0.5$ \\
5 & $\alpha>0.0121$ & $\alpha>0.5$ \\
\hline \hline
\end{tabular}

Notes: Calculation of range of risk aversion parameter is based on the number of riskless options taken in Table A3. 


\section{Hypothetical Insurance Take-up during the Game}

During each round of the game, participants make new take-up decisions based on their experience and information received in previous rounds of the game. In this section, we investigate hypothetical insurance take-up decisions during the game.

We create two indexes to study hypothetical insurance take-up during the game. The first one is an $S$ index which measures the switching behavior during the game. To construct the $S$ index, we first calculate the switching rate $C_{t}$, conditioned on whether a participant experienced a disaster in the previous round. A switch is defined to be $1(-1)$ if a participant switches from not buy (buy) to buy (not buy), and zero otherwise. We next calculate the switching rate $C_{t}$, which measures the switching rate across all participants for that round. This helps to capture the fixed effect of the year on switching decisions. The $S$ index thus measures the normalized switching rate conditional on whether participants experienced a disaster in the previous round.

$$
\begin{gathered}
C_{t} \mid \text { disaster }_{t-1}=\frac{\text { Switch }, d_{t-1}}{N, d_{t-1}} \\
\bar{C}_{t}=\frac{\text { Switch }}{N_{t-1}} \\
S_{t}=C_{t}-\bar{C}_{t}
\end{gathered}
$$

According to the results in Figure C1, conditioned on experiencing a disaster in a previous round, the $S$ index is positive in eight out of nine rounds, with the first two rounds exhibiting 
the largest $S$ indexes ${ }^{19}$. Since both take-up and switching behaviors are endogenous, this suggests that experiencing a disaster increases the likelihood of switching, with a greater effect of disaster experience in the first two rounds of the insurance game.

Our second index is an $L$ index that measures the insurance take-up conditional on disaster experience in the first round of the game. The formula for $L$ index is as following:

$$
L_{t}=\frac{E\left(\text { buyt }_{t} \mid \text { disaster }_{2011}\right)}{E\left(\text { buyt }_{t}\right)}=\frac{{\operatorname{Prob}\left(\text { takeup }_{t} \mid \text { disaster }_{2011}\right)}_{\text {Prob(takeup } \left._{t}\right)}}{\text { (tak }}
$$

The results in Figure $\mathrm{C} 2$ show the $L$ index across different rounds of the game. Conditioning on experiencing a disaster in the first round, we find a positive $L$ index across the subsequent nine rounds of the game. Furthermore, a two-sample t-test shows that, in each round, participants who experience a disaster in the first period are more likely to buy insurance; this effect is significant at $10 \%$ level for five of the nine subsequent rounds. A logistics regression shows that experiencing a disaster in the first round increases insurance take-up in the second period (significant at the $5 \%$ level) as well as in subsequent periods (significant at the $1 \%$ level). This suggests that experiencing a disaster in the first round of the game is effective in increasing follow-up insurance take-up throughout the rest of the game.

In sum, we find that experiencing hypothetical disasters increases insurance take-up rates during the game. These results are consistent with our explanation in Section 4.2.4 that hypothetical experience also increases actual insurance take-up. That is, if hypothetical experience drives our main treatment effects, then we should see an effect of hypothetical experience on both hypothetical and real insurance adoption behavior.

\footnotetext{
${ }^{19}$ A two-sample t-test shows that, in the first two rounds, the $S$ index is larger for participants who experienced a disaster in the previous round, significant at the $5 \%$ level. Furthermore, an ordered logistics regression shows that experiencing a disaster in first two rounds increases the probability of switching from not buying to buying; this result is significant at the $1 \%$ level
} 


\section{Figure C1. Switching Behavior during the Game}

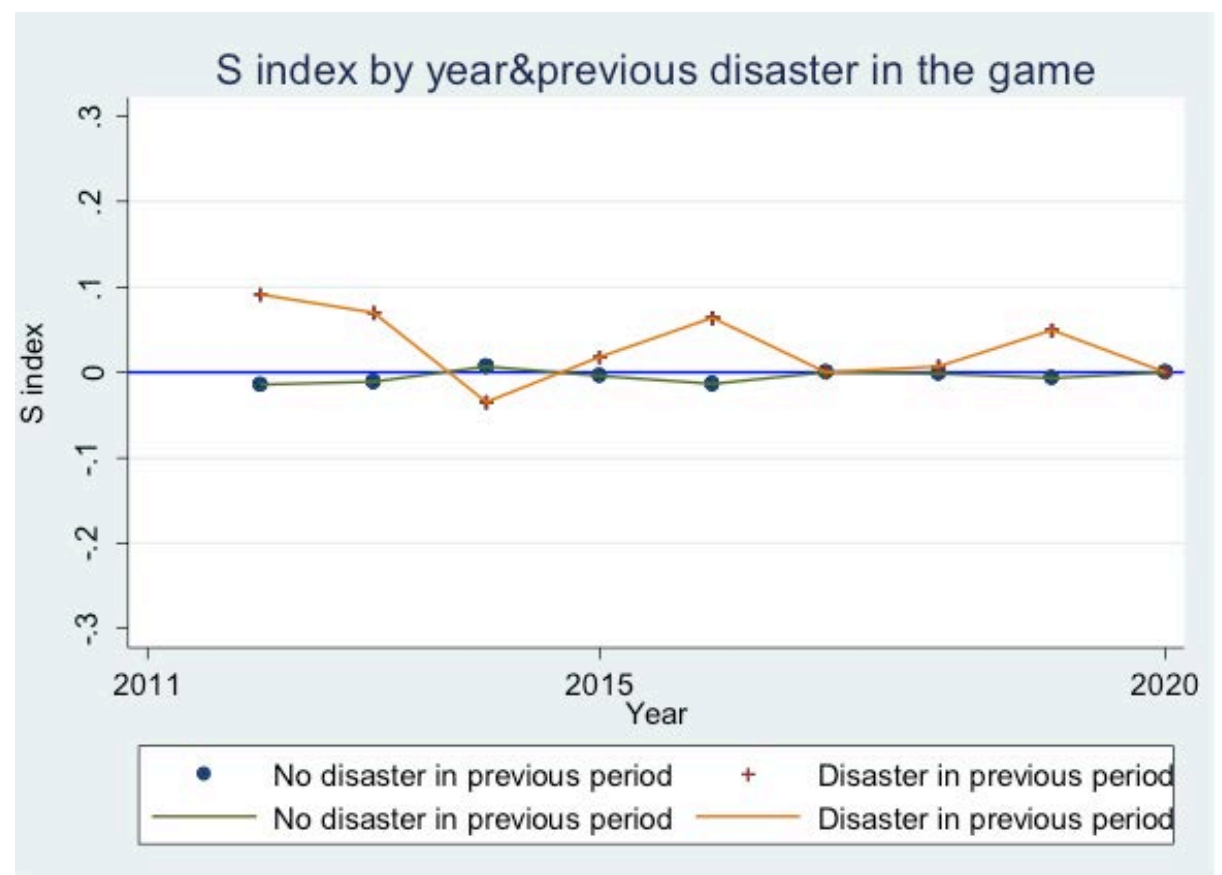

Notes: This figure presents the switching behavior during the game, measured by the $\mathrm{S}$ index. To construct the $\mathrm{S}$ index, we first calculate the switching rate $C_{t}$, conditioned on whether a participant experienced a disaster in the previous round. A switch is defined to be $1(-1)$ if a participant switches from not buy (buy) to buy (not buy), and zero otherwise. We next calculate the switching rate $C_{t}$, which measures the switching rate across all participants for that round. This helps to capture the fixed effect of the year on switching decisions. The $\mathrm{S}$ index thus measures the normalized switching rate conditional on whether participants experienced a disaster in the previous round. 
Figure $\mathrm{C} 2$. The impact of first round disaster

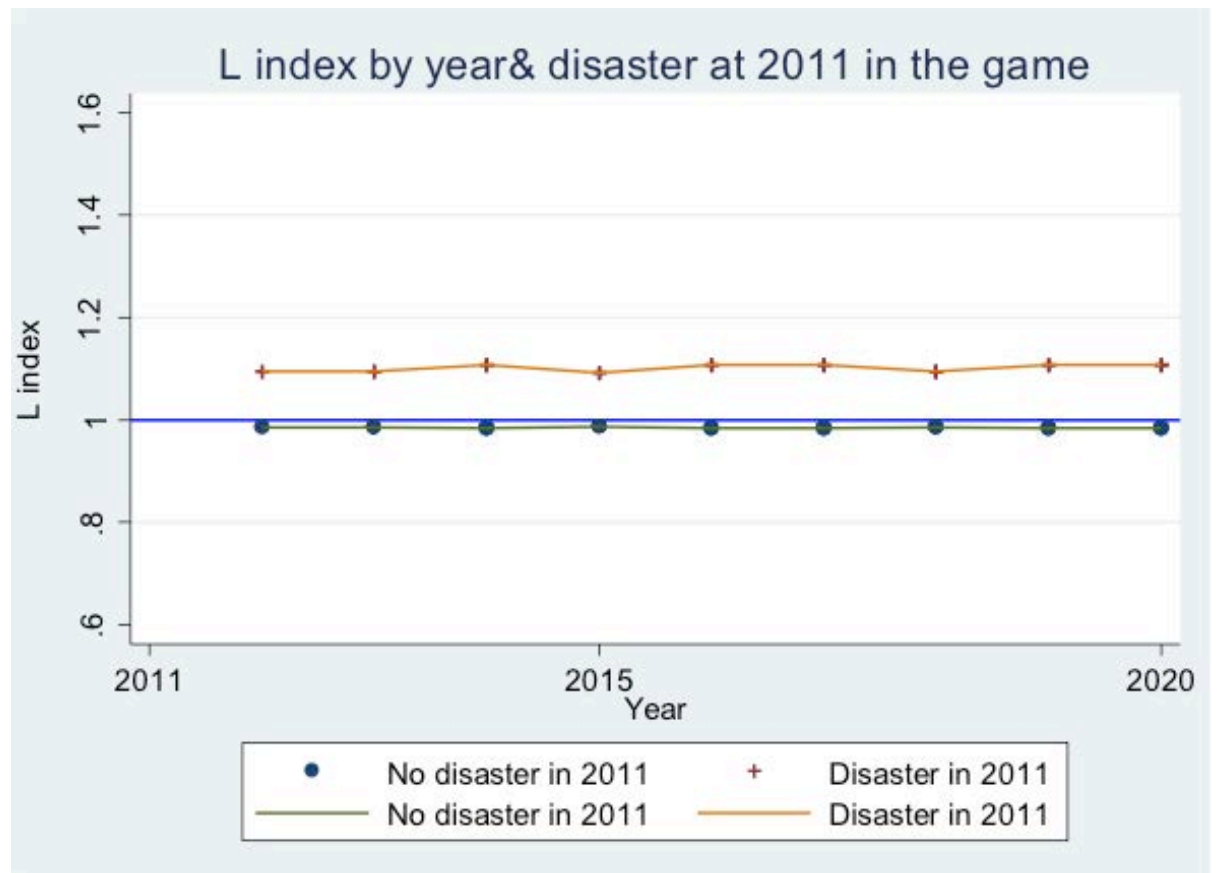

Notes: This figure shows the impact of first round hypothetical disasters on hypothetical insurance take-up during the game, measured by the L index. 


\section{Enumerators Instructions for different interventions}

\section{D.1 Only for household in $20 \%$ and $10 \%$ game group}

1. The purpose of this experiment/game is to help you understand how insurance works. "In every year in the next 10 years, you will be asked to decide whether to buy rice insurance or not, then the investigator will help you to calculate your income depending on your choice and whether a disaster happened, which will be determined by the poker that you drawn." Four steps:

- Ask "Now it is year 2010, you are producing $10 \mathrm{mu}$ rice, and the price of the rice insurance is $3.6 \mathrm{RMB} / \mathrm{mu}$ for one season. will you buy the insurance?"

- Ask why they buy or why not buy

- Draw a card to determine whether there is disaster this year

- Explain the income in that year according to Table D1

For example, if the household does not buy the insurance and there is disaster, the income in that year is 6000. Repeat the procedure for ten times and finish Part 2 of the survey depending on the farmer's choices. Before the game, do show the household that there is 1 or 2 disaster cards in 10 cards.

2. According to Table D2, finish the summary of the game and show the farmer the benefit to purchase insurance. For example, if there are 2 disasters in 10 years, then explain in the following way: "According to our insurance game, you have 2 disasters in next 10 years. Then if you did not purchase insurance in any year, you will lose 8000 and get total income 92000. If you purchased insurance every year, you should pay extra 360 but you 
should get reimbursement 1600. Total income if always buying is 1240 larger than total income if always not buying. Buying insurance is better. According to our calculation, if there is no large disaster in next 10 years, it is better to not buy any year. If there is at least 1 large disaster, it is better to buy insurance every year."

\section{D.2 Only for household in "Calculate insurance benefit" group}

Explain the benefit of insurance according Table D2: Now I will explain the benefit of the insurance. Consider whether you are going to buy insurance in the next 10 years.

- Consider there is no disaster in next 10 years. If you did not purchase insurance in any year, you will get total income 100000. If you purchased insurance every year, you should pay extra 360. Not buying insurance is better.

- Consider there is 1 disaster in next 10 years. If you did not purchase insurance in any year, you will lose 4000 and get total income 96000. If you purchased insurance every year, you should pay extra 360 but you should get reimbursement 800 . Total income if always buying is 440 larger than total income if always not buying. Buying insurance is better.

- Consider there is 2 disasters in next 10 years. If you did not purchase insurance in any year, you will lose 8000 and get total income 92000. If you purchased insurance every year, you should pay extra 360 but you should get reimbursement 1600. Total income if always buying is 1240 larger than total income if always not buying. Buying insurance is better.

- Consider there is 3 disasters in next 10 years. If you did not purchase insurance in any year, you will lose 12000 and get total income 88000. If you purchased insurance 
every year, you should pay extra 360 but you should get reimbursement 2400. Total income if always buying is 2040 larger than total income if always not buying. Buying insurance is better.

According to our calculation, if there is no large disaster in next 10 years, it is better to not buy any year. If there is at least 1 large disaster, it is better to buy insurance every year. 
Table D1. Explanation of the Insurance Benefit

\begin{tabular}{cccc}
\hline \hline Up-take & Disaster & $\begin{array}{c}\text { Income } \\
(\mathrm{RMB})\end{array}$ & Note \\
\hline NO & NO & $10000=1000 * 10 \mathrm{mu}$ & $\begin{array}{c}\text { Assume when there's no disaster, the gross income per } \\
\text { mu is 1000 RMB }\end{array}$ \\
\hline NO & YES & $6000=600 * 10$ & $\begin{array}{c}\text { Assume if a 40\% disaster happened, the gross income per mu } \\
\text { is 600 RMB }\end{array}$ \\
\hline YES & NO & $9964=1000 * 10-3.6 * 10$ & $\begin{array}{c}\text { Assume when there's no disaster, the gross income per } \\
\text { mu is 1000 RMB, and the premium is 36 RMB in total. }\end{array}$ \\
\hline \hline
\end{tabular}

Table D2. Summary of the Insurance Game

\begin{tabular}{|c|c|c|}
\hline $\begin{array}{c}\text { Number of } \\
\text { disasters in } \\
10 \text { years }\end{array}$ & $\begin{array}{c}\text { Total ten years' income if you purchased } \\
\text { insurance every year }\end{array}$ & $\begin{array}{l}\text { Total ten years' income if you did } \\
\text { not purchase insurance in any year }\end{array}$ \\
\hline 0 & $99640=10000-3.6 * 10 \mathrm{mu} * 10$ year & $100000=1000 * 10 \mathrm{mu} * 10$ year \\
\hline 1 & $96440=96000-360+200 * 40 \% * 10 \mathrm{mu} * 1$ year & $96000=100000-400 * 10 \mathrm{mu}^{*} 1$ year \\
\hline 2 & $93240=92000-360+200 * 40 \% * 10 \mathrm{mu} * 2$ year & $92000=100000-400 * 10 \mathrm{mu}^{*} 2$ year \\
\hline 3 & $90040=88000-360+200 * 40 \% * 10 \mathrm{mu}^{*} 3$ year & $88000=100000-400 * 10 \mathrm{mu}^{*} 3$ year \\
\hline 4 & $86840=84000-360+200 * 40 \% * 10 \mathrm{mu}^{*} 4$ year & $84000=100000-400 * 10 \mathrm{mu}^{*} 4$ year \\
\hline 5 & $83640=80000-360+200 * 40 \% * 10 \mathrm{mu} * 5 \mathrm{year}$ & $80000=100000-400 * 10 \mathrm{mu} * 5$ year \\
\hline 6 & $80440=76000-360+200 * 40 \% * 10 \mathrm{mu}^{*} 6 \mathrm{year}$ & $76000=100000-400 * 10 \mathrm{mu}^{*} 6$ year \\
\hline 7 & $77240=72000-360+200 * 40 \% * 10 \mathrm{mu} * 7$ year & $72000=100000-400 * 10 \mathrm{mu}^{*} 7$ year \\
\hline 8 & $74040=68000-360+200 * 40 \% * 10 \mathrm{mu} * 8$ year & $68000=100000-400 * 10 \mathrm{mu}^{*} 8$ year \\
\hline
\end{tabular}

